Gian Paolo Stella

Umberto Filotto

Enrico Maria Cervellati

\author{
FINANCIAL \\ LITERACY IN ITALY: \\ EMPIRICAL EVIDENCE \\ AND THEORETICAL \\ PROPOSALS
}




\section{FINANCIAL LITERACY IN ITALY: \\ EMPIRICAL EVIDENCE AND THEORETICAL PROPOSALS}

Gian Paolo Stella

Umberto Filotto Enrico Maria Cervellati

\begin{tabular}{|c|c|c|}
\hline 名誉 & 良心 & 高貴 \\
\hline & & ouki \\
\hline Hono & Conscience & $\mathcal{N}$ obi \\
\hline
\end{tabular}




\section{VIRTUS NTERPRESS}

Published in Ukraine by Virtus Interpress

(C) The Authors, 2021

All parts of this publication may be used according to the Creative Commons Attribution 4.0 International License (CC $B Y$ 4.0) https://creativecommons.org/licenses/by/4.0/

New orders of the textbook and enquires concerning reproduction outside the scope of the above should be sent to:

Virtus Interpress

Gagarina Str. 9, 311

Sumy, 40000

Ukraine

www.virtusinterpress.org

Stella, G. P., Filotto, U., \& Cervellati, E. M. (2021). Financial literacy in Italy: Empirical evidence and theoretical proposals. https://doi.org/10.22495/flieetp

You must not circulate this book in any other binding or cover and you must impose this same condition on any acquirer.

ISBN 978-617-7309-19-1 


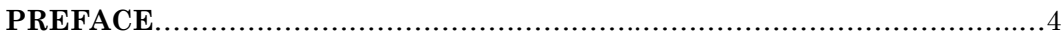

CHAPTER 1. TRADITIONAL FINANCE APPROACH TO

FINANCIAL LITERACY

1.1. Introduction 6

1.2. Financial literacy assessment techniques and definitions........................ 7

1.3. The role of financial knowledge to determine financial literacy .................10

1.4. Brief literature review on the determinants of financial literacy ..............11

\section{CHAPTER 2. BEHAVIOURAL FINANCE APPROACH TO}

\section{FINANCIAL LITERACY}

2.1. Introduction

2.2. The IOSCO-OECD 2018 report on the application of behavioural insights to financial literacy and investor education programmes and initiatives

2.3. Applications of BIs to financial literacy/investor education programmes in Italy

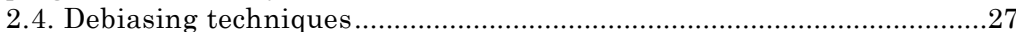

2.5. Approaches for applying behavioural insights .....................................30

\section{CHAPTER 3. PERSONALITY TRAITS AND BEHAVIOURAL} PROPENSITIES

3.1. Introduction

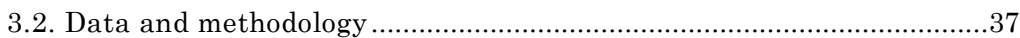

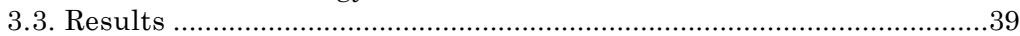

\section{CHAPTER 4. FINANCIAL LITERACY AS AN INDICATOR OF}

ECONOMIC INEQUALITIES BETWEEN ITALIAN REGIONS

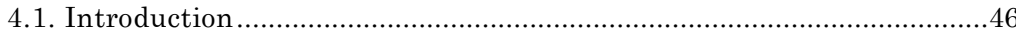

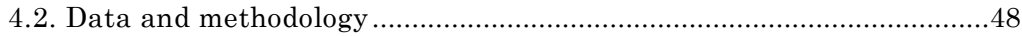

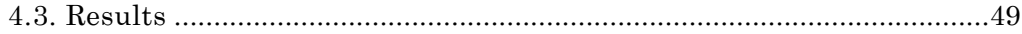

4.4. Concluding remarks and research perspectives .............................55 


\section{PREFACE}

The purpose of this book is to analyse financial literacy from theoretical and empirical points of view, with a particular focus on the evidence related to Italy. This work is motivated by the increasing complexity of financial instruments as well as by the evolution of individuals' needs that result in the need to implement measures to increase individuals' financial literacy. Since financial literacy level seems to determine an individual's position in the financial system relative to other economic agents, financial illiteracy or the lack of financial knowledge and skills can lead to lifelong financial hardships (Lusardi \& Mitchell, 2011). In this regard, a sufficient degree of financial literacy is a necessary condition for financial welfare (Lusardi \& Mitchell, 2011).

We divide the book into two parts. In part 1, we present an extended and critical comparison of previous studies and evidence related to financial literacy at an international level, both from traditional finance (Chapter 1) and behavioural finance (Chapter 2) points of view. In part 2, instead, we present evidence related to financial literacy in Italy, documented through our own empirical findings.

In Chapter 3, we analyse the relationship between behavioural propensities, financial literacy, and personality traits using a survey of Italian respondents. We administered a questionnaire including questions on the basic measures of financial knowledge proposed by Lusardi and Mitchell (2011), as well as on personality traits - a reduced version of the so-called "Big Five" personality traits approach (Gosling, Rentfrow, \& Swann, 2003) - and behavioural propensities (Pan \& Statman, 2013).

In Chapter 4, we show how the differences in gross domestic product (GDP) between Italian macro-regions are associated with financial literacy proxies. Italy represents a useful case study to analyse the effects and consequences related to financial literacy because Italians generally have low literacy on financial topics (Klapper, Lusardi, \& van Oudheusden, 2015; di Salvatore, Franceschi, Neri, \& Zanichelli, 2018). Northern and central regions with high GDP show a higher level of financial literacy, while southern regions and islands present lower GDP and financial literacy levels. For our objective, it is important to implement a new methodology, combining the measures already used in past studies as well as new variables which enable a better understanding of financial literacy. The choice of investigating financial literacy levels by combining as key variables skills and attitudes along with knowledge in the financial realm is motivated by the necessity of conducting a more in-depth investigation of the causes of financial illiteracy. To measure financial attitudes and skills, we introduce a new set of items designed following the guidelines provided by the Organization for Economic Co-operation and Development (OECD, 2016). 
Furthermore, considering both skills and attitudes results in a more accurate picture of various aspects pertaining to financial literacy, which makes it possible to determine what aspects of financial decisions processes are affected regarding levels of financial literacy.

\section{Gian Paolo Stella \\ Umberto Filotto \\ Enrico Maria Cervellati}

\section{References}

1. di Salvatore, A., Franceschi, F., Neri, A., \& Zanichelli, F. (2018). Measuring the financial literacy of the adult population: The experience of Banca d'Italia (Bank of Italy Occasional Paper No. 435). https://doi.org/10.2139/ssrn.3212627

2. Gosling, S. D., Rentfrow, P. J., \& Swann, W. B., Jr. (2003). A very brief measure of the Big-Five personality domains. Journal of Research in Personality, 37(6), 504-528. https://doi.org/10.1016/S0092-6566(03)00046-1

3. Klapper, L., Lusardi, A., \& van Oudheusden, P. (2015). Financial literacy around the world: Insights from the Standard \& Poor's ratings services global financial literacy survey (World Bank Report). Retrieved from http://nzz-filesprod.s3-website-eu-west-1.amazonaws.com/files/1/8/1/2015-Finlit_paper _17_F3_SINGLES_1.18658181.pdf

4. Lusardi, A., \& Mitchell, O. S. (2011). The outlook for financial literacy (NBER Working Paper No. 17077). https://doi.org/10.3386/w17077

5. OECD. (2016). G20/OECD INFE: Core competencies framework on financial literacy for adults. Retrieved from https://www.oecd.org/finance/CoreCompetencies-Framework-Adults.pdf

6. Pan, C. H., \& Statman, M. (2013). Investor personality in investor questionnaires. Journal of Investment Consulting, 14(1), 48-56. https://doi.org/10.2139/ssrn.2022339 


\section{TRADITIONAL FINANCE APPROACH TO FINANCIAL LITERACY}

\subsection{Introduction}

The past economic crisis significantly damaged the global financial system and the economic stability of many individuals, emphasizing their poor financial knowledge and financial skills, which did not allow them to protect themselves from the negative impacts of the crisis (Lusardi \& Mitchell, 2011a; Atkinson \& Messy, 2012; Klapper, Lusardi, \& van Oudheusden, 2015). While it is not possible to prevent sudden negative economic shocks, it is possible to intervene and to reduce the effects of such shocks (Lusardi, Mitchell, \& Curto, 2010). For many years, financial knowledge has been synonymous with financial literacy (Hilgert, Hogarth, \& Beverly, 2003; Lusardi \& Mitchell, 2011b; Bucher-Koenen, Lusardi, Alessie, \& van Rooij, 2017). Nevertheless, some scholars disagreed, highlighting that financial knowledge is not sufficient to fully describe financial literacy (Kimiyaghalam \& Safari, 2015). The efforts made by scholars on financial literacy, together with the initiatives promoted by public and private authorities to increase financial knowledge, had positive effects, but they are still not sufficient (OECD, 2016; Lusardi \& Mitchell, 2011b).

Financial knowledge is certainly an important construct but alone is not able to explain the reasons for individuals' poor financial choices (Allgood \& Walstad, 2013; Klapper et al., 2015). For example, Allgood and Walstad (2013) investigate the gap between knowledge and decisions in the financial field by focusing on the concept of competence. Other researchers studied financial literacy by testing the variables that influence individuals' choices and decision-making mechanisms. The development of such measurement techniques simultaneously occurred to the identification of these variables. As a result, other variables that play a key role in financial literacy were identified. In addition to the evolution of observation techniques, prior studies performed joint analyses of both economic and psychological aspects, recognising that connecting knowledge to behaviour is fundamental to identify the cognitive and emotional errors that individuals commit in taking financial decisions. They found that even individuals with strong financial knowledge can make mistakes in their financial choices, highlighting the need to delve more deeply into aspects related to the psychological nature of decisions. As mentioned in the Introduction, we devote Chapter 2 to the behavioural aspects related to financial literacy. In this chapter, instead, we address the traditional approach, starting with a literature review of the main studies in the field, as well as on the methodologies typically used to measure financial literacy. 


\subsection{Financial literacy assessment techniques and definitions}

Researchers have shown that bad financial choices are linked to low financial literacy levels (Allgood \& Walstad, 2013; Klapper et al., 2015). In particular, the relationship between financial literacy and financial behaviour is fundamental because improving financial literacy would enable people to make better financial decisions and create conditions to improve their well-being (Lusardi et al., 2010). Therefore, determining the variables that indicate and measure financial literacy is important.

Before introducing the financial literacy variables, it is necessary to explain their components. Each variable is composed of a set of items that have the goal to explain the reference latent variable. Lusardi and Mitchel (2007a) identified the items to measure financial knowledge, proposing three questions regarding knowledge of compound interest rates, real return rates, and risk diversification that became widespread and are now known as the "Big Three". Subsequently, two other items based on knowledge on mortgages and bond pricing were added to the three initial questions, now forming the so-called "Big Five". Therefore, each financial literacy variable depends on arguments that the authors consider more relevant compared to others. Furthermore, one other key aspect in terms of financial literacy measurement is to verify the strategies used to measure the issue under study. Scholars used both "performance test" and "self-report" methods to measure financial literacy. The choice between these two methods depends on the treatments of the results (see Table 1). Self-assessment tends to be biased by respondents' overconfidence in their actual knowledge or competence (OECD, 2005). On the other hand, also performance tests pose some challenges in measuring financial knowledge or competence because the interviewed person must choose a single option that can be true or false. Agnew and Szykman (2005) found a significant correlation between actual and perceived financial knowledge. A robust methodology capable of measuring financial literacy must thus be developed through variables based on both self-report and performance test approaches.

Since financial knowledge is a fundamental construct to predict financial literacy, in most definitions, the presence of financial knowledge indicates financial literacy (see Table 2). 


\section{Table 1. Financial literacy assessment technique}

\begin{tabular}{|c|c|c|c|c|}
\hline Author & Title & Year & $P T$ & $S A$ \\
\hline $\begin{array}{l}\text { Volpe, Chen, } \\
\text { Pavlicko }\end{array}$ & $\begin{array}{l}\text { Personal investment literacy among college students: } \\
\text { A survey. }\end{array}$ & 1996 & $x$ & \\
\hline Chen, Volpe & $\begin{array}{l}\text { An analysis of personal financial literacy among college } \\
\text { students. }\end{array}$ & 1998 & $x$ & \\
\hline $\begin{array}{l}\text { Volpe, Kotek, } \\
\text { Chen }\end{array}$ & A survey of investment literacy among online investors. & 2002 & $x$ & \\
\hline $\begin{array}{l}\text { Hilgert, } \\
\text { Hogarth, } \\
\text { Beverley }\end{array}$ & $\begin{array}{l}\text { Household financial management: The connection } \\
\text { between knowledge and behaviour. }\end{array}$ & 2003 & $x$ & \\
\hline FINRA & NASD investor literacy research: Executive summary. & 2003 & $\times$ & $x$ \\
\hline Moore & $\begin{array}{l}\text { Survey of financial literacy in Washington State: } \\
\text { Knowledge, behaviour, attitudes, and experiences. }\end{array}$ & 2003 & $x$ & $x$ \\
\hline Mandell & $\begin{array}{l}\text { Financial literacy: If it's so important, why isn't it } \\
\text { improving? }\end{array}$ & 2006 & $x$ & \\
\hline $\begin{array}{l}\text { Agnew, } \\
\text { Szykman }\end{array}$ & $\begin{array}{l}\text { Asset allocation and information overload: The } \\
\text { influence of information display, asset choice, and } \\
\text { investor experience }\end{array}$ & 2005 & $x$ & $x$ \\
\hline $\begin{array}{l}\text { Markow, } \\
\text { Bagnaschi }\end{array}$ & What American teens \& adults know about economics. & 2005 & $x$ & \\
\hline $\begin{array}{l}\text { Lusardi, } \\
\text { Mitchell }\end{array}$ & $\begin{array}{l}\text { inancial literacy and retirement planning: New } \\
\text { vidence from the Rand American Life Panel. }\end{array}$ & 2007 & $x$ & \\
\hline $\begin{array}{l}\text { Lusardi, } \\
\text { Mitchell }\end{array}$ & $\begin{array}{l}\text { Baby boomer retirement security: The roles of } \\
\text { planning, financial literacy, and housing wealth. }\end{array}$ & 2007 & $x$ & $x$ \\
\hline Mandell & inancial literacy of high school students. & 2008 & $\times$ & \\
\hline $\begin{array}{l}\text { van Rooij, } \\
\text { Lusardi, } A\end{array}$ & Financial literacy and stock market participation. & 2011 & $x$ & \\
\hline $\begin{array}{l}\text { Lusardi, } \\
\text { Mitchell }\end{array}$ & $\begin{array}{l}\text { Financial literacy and planning: Implications for } \\
\text { retirement wellbeing. }\end{array}$ & 2011 & $x$ & \\
\hline Lusardi, Tufano & $\begin{array}{l}\text { Debt literacy, financial experiences, and } \\
\text { overindebtedness. }\end{array}$ & 2015 & $x$ & \\
\hline $\begin{array}{l}\text { Fornero, } \\
\text { Monticone }\end{array}$ & $\begin{array}{l}\text { Financial literacy and pension plan participation in } \\
\text { Italy. }\end{array}$ & 2011 & $x$ & $x$ \\
\hline $\begin{array}{l}\text { van Rooij, } \\
\text { Lusardi, Alessie }\end{array}$ & $\begin{array}{l}\text { nancial literacy, retirement planning and household } \\
\text { ealth }\end{array}$ & 2012 & $x$ & $x$ \\
\hline Mottola & $\begin{array}{l}\text { In our best interest: Women, financial literacy, and } \\
\text { credit card behaviour. }\end{array}$ & 2013 & $x$ & $x$ \\
\hline $\begin{array}{l}\text { Lusardi, } \\
\text { Mitchell }\end{array}$ & $\begin{array}{l}\text { The economic importance of financial literacy: Theory } \\
\text { and evidence. }\end{array}$ & 2014 & $x$ & $x$ \\
\hline Kramer & $\begin{array}{l}\text { Financial literacy, confidence and financial advice } \\
\text { seeking. }\end{array}$ & 2016 & $x$ & $x$ \\
\hline von Gaudecker & $\begin{array}{l}\text { How does household portfolio diversification vary with } \\
\text { financial literacy and financial advice? }\end{array}$ & 2015 & $x$ & $x$ \\
\hline $\begin{array}{l}\text { Gamble, Boyle, } \\
\text { Yu, Bennett }\end{array}$ & Aging and financial decision making. & 2014 & $x$ & $x$ \\
\hline $\begin{array}{l}\text { Klapper, } \\
\text { Lusardi, } \\
\text { van Oudheusden }\end{array}$ & $\begin{array}{l}\text { Financial literacy around the world: Insights from the } \\
\text { Standard \& Poor's ratings services global financial } \\
\text { literacy survey. }\end{array}$ & 2015 & $x$ & \\
\hline $\begin{array}{l}\text { Allgood, } \\
\text { Walstad }\end{array}$ & $\begin{array}{l}\text { The effects of perceived and actual financial literacy on } \\
\text { financial behaviour. }\end{array}$ & 2016 & $x$ & $x$ \\
\hline & $\begin{array}{l}\text { Actual and perceived financial sophistication and } \\
\text { wealth accumulation: The role of education and gender. }\end{array}$ & 2016 & $x$ & $x$ \\
\hline $\begin{array}{l}\text { Bucher-Koenen, } \\
\text { Lusardi, Alessie, } \\
\text { van Rooij }\end{array}$ & $\begin{array}{l}\text { How financially literate are women? An overview and } \\
\text { new insights. }\end{array}$ & 2017 & $x$ & $x$ \\
\hline
\end{tabular}

Note: PT stands for "performance test", SA for "self-assessed". 


\section{Table 2. Financial literacy definitions}

\begin{tabular}{|l|l|}
\hline \multicolumn{1}{|c|}{ Authors } & \multicolumn{1}{c|}{ Definition } \\
\hline $\begin{array}{l}\text { Noctor, Stoney, and } \\
\text { Stradling (1992) }\end{array}$ & $\begin{array}{l}\text { "The ability to make informed judgments and to make effective } \\
\text { decisions regarding the use and management of money". }\end{array}$ \\
\hline $\begin{array}{l}\text { Jump\$tart Coalition } \\
\text { (2017) }\end{array}$ & $\begin{array}{l}\text { "The ability to use knowledge and skills to manage one's } \\
\text { financial resources effectively for lifetime financial security". }\end{array}$ \\
\hline $\begin{array}{l}\text { Financial Industry } \\
\text { Regulatory Authority } \\
\text { (FINRA) (2003) }\end{array}$ & $\begin{array}{l}\text { "The understanding ordinary investors have of market } \\
\text { principles, instruments, organisations and regulations". }\end{array}$ \\
\hline Mandell (2006) & $\begin{array}{l}\text { "The ability to evaluate the new and complex financial } \\
\text { instruments and make informed judgments in both choice of } \\
\text { instruments and extent of use that would be in their own best } \\
\text { long-run interests". }\end{array}$ \\
\hline $\begin{array}{l}\text { Hung, Parker, and } \\
\text { Yoong (2009) }\end{array}$ & $\begin{array}{l}\text { "Knowledge of basic economic and financial concepts, as well as } \\
\text { the ability to use that knowledge and other financial skills to } \\
\text { manage financial resources effectively for a lifetime of financial } \\
\text { well-being". }\end{array}$ \\
\hline Huston (2010) & $\begin{array}{l}\text { "Understanding (personal finance knowledge) and use (personal } \\
\text { finance application). }\end{array}$ \\
\hline $\begin{array}{l}\text { Atkinson and Messy } \\
\text { (2012) }\end{array}$ & $\begin{array}{l}\text { "Amalgam of mindfulness, attitude, behaviours and knowledge } \\
\text { and skills essential for making the right financial decisions } \\
\text { which eventually lead to the attainment of financial wellbeing". }\end{array}$ \\
\hline $\begin{array}{l}\text { Organization for } \\
\text { Economic Co-operation } \\
\text { and Development } \\
\text { (OECD) (2014) }\end{array}$ & $\begin{array}{l}\text { "Knowledge and understanding of financial concepts and risks, } \\
\text { and the skills, motivation and confidence to apply such } \\
\text { knowledge and understanding in order to make effective } \\
\text { decisions across a range of financial contexts, to improve the } \\
\text { financial well-being of individuals and society, and to enable } \\
\text { participation in economic life". }\end{array}$ \\
\hline $\begin{array}{l}\text { Lusardi and Mitchell } \\
\text { (2014) }\end{array}$ & $\begin{array}{l}\text { "People's ability to process economics and make informed } \\
\text { decisions about financial planning, wealth accumulation, debt, } \\
\text { and pensions secure personal income". }\end{array}$ \\
\hline
\end{tabular}

Source: Authors' elaboration from mentioned studies.

The different definitions proposed in the literature (Table 2) clarify that both knowledge and skills are fundamental to determine the level of financial literacy. Furthermore, the effective application of skills is provided by competencies. Wuttke and Aprea (2018) first introduced financial competence to predict German young adults' financial literacy level. The focus of the competence questions was on everyday financial themes such as purchase decisions. The assessment analysed competencies on safety about financial fraud due, for example, to the loss of credit cards or entering personal data on unknown internet sites. Regarding the assessment technique, the questionnaire was designed on both performance test and self-report methods. This methodology added to financial literacy literature by including financial competence as a determinant and significant predictor of financial literacy. 


\subsection{The role of financial knowledge to determine financial literacy}

Since the early 1990s, the Consumer Confederation of America conducted the so-called "Consumer Knowledge" surveys on different populations, including questions on consumer credit, bank accounts, etc. Subsequently, the measurement of financial literacy levels included questions on financial knowledge. According to Hilgert et al. (2003), financial literacy and financial knowledge mean the same thing. In fact, the "Big Three" questions of the Health and Retirement Study (HRS) 2004 financial literacy model were incorporated into the 2009 National Financial Capacity Study (NFCS) conducted in the United States, adding the two additional financial literacy questions on knowledge of mortgage interest rates and bond prices, to form the "Big Five." In measuring financial literacy through financial knowledge, it is necessary to distinguish general knowledge from specific knowledge on financial topics. Although financial knowledge is considered fundamental to understand financial literacy, it is necessary to analyse it not in general outlines, but in specific financial fields. Some authors consider a specific knowledge of finance to be better than the general knowledge of finance to predict performance on a hypothetical investment task (Hung, Parker, \& Yoong, 2009). In accordance with this approach, researchers use a single personal finance area such as investments (Volpe, Chen, \& Pavlicko, 1996), the stock market (FINRA, 2003), credit and debt (Lusardi \& Tufano, 2009) to assess financial knowledge.

While the importance of financial competence in financial literacy has been widely acknowledged in the literature, several studies proposed to go beyond competence to explain literacy. For example, Noctor, Stoney, and Stradling (1992) defined financial literacy as "the ability to make informed judgments and to make effective decisions regarding the use and management of money" (p. 12). Beal and Delpachitra (2003) and Worthington (2006) showed that the consumers' judgments and abilities was the focus of financial literacy.

Considering only knowledge is, therefore, inadequate to measure the degree of financial literacy (Kimiyaghalam \& Safari, 2015). In the Jump\$tart Coalition's (2017) definition, reference is made not only to knowledge but also to "the ability to use it and skills to manage one's financial resources effectively for lifetime security" (p. 1). Johnson and Sherraden (2007) provided a definition of financial literacy that combines financial knowledge and the ability to apply that knowledge. They stated that "participation in economic life should maximize life chances and enable people to lead fulfilling lives; this requires knowledge and competencies, ability to act on that knowledge and opportunity to act" (Johnson \& Sherraden, 2007, p. 118). Thus, research on financial literacy cannot ignore the issue of skills: it is essential to emphasize that knowledge is the core of skills, and without the study of these it is not possible to infer anything, especially in terms of financial literacy. 


\subsection{Brief literature review on the determinants of financial literacy}

Among possible determinants of financial literacy, studies in the literature found age to be a variable of considerable interest. Some scholars claimed that younger and older people seem to possess lower levels of financial literacy relative to middle-aged adults (Agarwal, Driscoll, Gabaix, \& Laibson, 2009; Beckmann, 2013; Worthington, 2006). Also, Lusardi and Mitchell (2011c) showed that the age group between 25 and 65 achieved better results than the age group of those aged under 25 or over 65 . However, scholars have not been unanimous in their opinions regarding age.

Other studies (Monticone, 2010; Atkinson \& Messey, 2012) showed that also income levels and employment are correlated with levels of financial literacy. Johnson and Sherraden (2007) found that wealthier students had higher levels of financial literacy compared to poorer ones. According to Chen and Volpe (1998) ${ }^{1}$, individuals who have extensive working experience are more likely to have higher levels of literacy than those with more limited work experience. A link between the contributions provided by Chen and Volpe (1998) and Johnson and Sherraden (2007) refers to the influence that relatives have on younger people in terms of financial literacy. Specifically, parents play a key role in their children's financial literacy development (Chiteji \& Stafford, 1999; Jorgensen, 2007; Kim, LaTaillade, \& Kim, 2011; Lachance, 2012; Shim, Barber, Card, Xiao, \& Serido, 2010; Shim, Serido, Tang, \& Card, 2015). Young people learn not only financial concepts but also behaviours - such as how to save - observing parents' ones (Clarke, Heaton, Israelson, \& Eggert, 2005). Bruhn, de Souza Leão, Legovini, Marchetti, and Zia (2013) suggest that the dialogue between parents and children regarding financial issues increases the likelihood that children will have high levels of financial literacy. Shim et al. (2015) affirm that a link exists between parents and children in terms of financial literacy. Encouraging family members to attend seminars to learn key financial concepts altogether seems to increase children's level of financial literacy (Bruhn et al., 2013). Chiteji and Stafford (1999) found that the likelihood of a young person having financially correct behaviour in adulthood is highly correlated with the financial behaviour parents learned at an early age. The influence of families on young people, however, is different depending on the children's gender. Edwards, Allen, and Hayhoe (2007) showed how financial education transmitted in the family context can result in different levels of financial literacy for men and women. In fact, the differences between the levels of men's and women's financial literacy play an important role for both economic and social purposes. The literature reveals that women have lower levels of financial literacy than men (Chen \& Volpe, 1998, 2002;

\footnotetext{
${ }^{1}$ Chen and Volpe (1998) also show that, in the United States, impatient individuals are more likely to incur into debt. This behaviour is confirmed by O'Guinn and Faber (1989) that show how impatient individuals tend to possess several credit cards.
} 
Eckel \& Grossman, 2008; Murphy, 2005; Goldsmith \& Goldsmith, 2006; Lusardi \& Mitchell, 2007b, 2008; Robb \& James, 2009; Agnew \& Harrison, 2015; Lusardi, 2015). Studies show that men are more competent in investment and savings (Chen \& Volpe, 1998; Goldsmith \& Goldsmith, 2006) and more risk-prone (Agnew, Szykman, Utkus, \& Young, 2007) than women. The financial literacy gap between women and men affects women of all ages (Chen \& Volpe, 2002; Fonseca, Mullen, Zamarro, \& Zissimopoulos, 2012; Lusardi, 2015). The difference between men's and women's levels of financial literacy has been found in both developing and more developed countries (Lusardi \& Mitchell, 2011a).

The literature also identifies religion as a relevant variable for explaining levels of financial literacy (Weaver \& Agle, 2002; Hilary \& Hui, 2009; Shu, Sulaeman, \& Yeung, 2012). Renneboog and Spaenjers (2009) found financial literacy and religion to be correlated. Their analysis shows that believers have less propensity toward risk and greater tendencies to save money.

Another variable related to financial literacy is the level of financial satisfaction/dissatisfaction (Joo \& Grable, 2004; Bell, Gorin, \& Hogarth, 2009; Lambert et al., 2010; Murphy, 2013). Civil status is also correlated with financial literacy (Dew, 2008; Calamato, 2010; Brown \& Graf, 2013).

\section{References}

1. Agarwal, S., Driscoll, J. C., Gabaix, X., \& Laibson, D. (2009). The age of reason: Financial decisions over the life cycle and implications for regulation. Brookings Papers on Economic Activity, 2009(2), 51-117. https://doi.org/10.1353/eca.0.0067

2. Agnew, J. R., \& Szykman, L. R. (2005). Asset allocation and information overload: The influence of information display, asset choice, and investor experience. Journal of Behavioural Finance, 6(2), 57-70. https://doi.org/10.1207/s15427579jpfm0602_2

3. Agnew, J. R., Szykman, L. R., Utkus, S. P., \& Young, J. A. (2007). Literacy, trust and 401(K) savings behavior. https://doi.org/10.2139/ssrn.1299171

4. Agnew, S., \& Harrison, N. (2015). Financial literacy and student attitudes to debt: A cross national study examining the influence of gender on personal finance concepts. Journal of Retailing and Consumer Services, 25, 122-129. https://doi.org/10.1016/j.jretconser.2015.04.006

5. Agnew, S., Maras, P., \& Moon, A. (2018). Gender differences in financial socialization in the home - An exploratory study. International Journal of Consumer Studies, 42(3), 275-282. https://doi.org/10.1111/ijcs.12415

6. Allgood, S., \& Walstad, W. B. (2013). Financial literacy and credit card behaviours: A cross-sectional analysis by age. Numeracy, 6(2), 3. https://doi.org/10.5038/1936-4660.6.2.3

7. Allgood, S., \& Walstad, W. B. (2016). The effects of perceived and actual financial literacy on financial behaviours. Economic Inquiry, 54(1), 675-697. https://doi.org/10.1111/ecin.12255

8. Atkinson, A., \& Messy, F.-A. (2012). Measuring financial literacy: Results of the OECD/International Network on Financial Education (INFE) pilot study (OECD Working Paper No. 15). https://doi.org/10.1787/5k9csfs90fr4-en 
9. Bannier, C. E., \& Schwarz, M. (2016). Actual and perceived financial sophistication and wealth accumulation: The role of education and gender (CFS Working Paper No. 528). https://doi.org/10.2139/ssrn.2723860

10. Beal, D. J., \& Delpachitra, S. B. (2003). Financial literacy among Australian university students. Economic Papers: A Journal of Applied Economics and Policy, 22(1), 65-78. https://doi.org/10.1111/j.1759-3441.2003.tb00337.x

11. Beckmann, E. (2013). Financial literacy and household savings in Romania. Numeracy, 6(2), 9. https://doi.org/10.5038/1936-4660.6.2.9

12. Bell, C. J., Gorin, D. R., \& Hogarth, J. M. (2009). Does financial education affect soldiers' financial behavior? (Networks Financial Institute Working Paper No. 2009-WP-08). https://doi.org/10.2139/ssrn.1445635

13. Bentler, P. M. (1990). Comparative fit indexes in structural models. Psychological Bulletin, 107(2), 238-246. https://doi.org/10.1037//00332909.107.2.238

14. Bernanke, B. S. (2010, April 13). Fostering financial literacy [Speech]. National Bankers Association Foundation Financial Literacy Summit Reception, Washington, D.C. Retrieved from https://www.federalreserve.gov/ newsevents/speech/bernanke20100413a.htm

15. Bottazzi, L., \& Lusardi, A. (2016). Gender differences in financial literacy: Evidence from PISA data in Italy (Global Financial Literacy Excellence Center (GFLEC) Working Paper). Retrieved from https://institute.eib.org/wpcontent/uploads/2016/10/gender-diff.pdf

16. Brown, M., \& Graf, R. (2013). Financial literacy and retirement planning in Switzerland. Numeracy, 6(2), 6. https://doi.org/10.5038/1936-4660.6.2.6

17. Bruhn, M., de Souza Leão, L., Legovini, A., Marchetti, R., \& Zia, B. (2013). The impact of high school financial education: Experimental evidence from Brazil (World Bank Policy Research Working Paper No. 6723). https://doi.org/10.1596/1813-9450-6723

18. Bucher-Koenen, T., \& Lusardi, A. (2011). Financial literacy and retirement planning in Germany. Journal of Pension Economics \& Finance, 10(4), 565-584. https://doi.org/10.1017/S1474747211000485

19. Bucher-Koenen, T., Lusardi, A., Alessie, R., \& van Rooij, M. (2017). How financially literate are women? An overview and new insights. The Journal of Consumer Affairs, 51(2), 255-283. https://doi.org/10.1111/joca.12121

20. Calamato, M. P. (2010). Learning financial literacy in the family (Doctoral dissertation, San Jose State University). https://doi.org/10.31979/etd.4e8a-5y4r

21. Chen, H., \& Volpe, R. P. (1998). An analysis of personal financial literacy among college students. Financial Services Review, 7(2), 107-128. https://doi.org/10.1016/S1057-0810(99)80006-7

22. Chen, H., \& Volpe, R. P. (2002). Gender differences in personal financial literacy among college students. Financial Services Review, 11(3), 289-307. Retrieved from https://www.researchgate.net/publication/285358406_Gender _Differences_in_Personal_Financial_Literacy_Among_College_Students

23. Chiteji, N. S., \& Stafford, F. P. (1999). Portfolio choices of parents and their children as young adults: Asset accumulation by African-American families. American Economic Review, 89(2), 377-380. https://doi.org/10.1257/aer.89.2.377

24. Christelis, D., Jappelli, T., \& Padula, M. (2010). Cognitive abilities and portfolio choice. European Economic Review, 54(1), 18-38. https://doi.org/10.1016/j.euroecorev.2009.04.001

25. Clarke, M. C., Heaton, M. B., Israelson, C. L., \& Eggert, D. L. (2005). The acquisition of family financial roles and responsibilities. Family and Consumer Sciences Research Journal, 33(4), 321-340. https://doi.org/10.1177/1077727X04274117 
26. Collins, J. M. (2012). Financial advice: A substitute for financial literacy? Financial Services Review, 21(4), 307-322. https://doi.org/10.2139/ssrn.2046227

27. Danes, S. M. (1994). Parental perceptions of children's financial socialization. Financial Counseling and Planning, 5(1), 127-149. Retrieved from https://experts.umn.edu/en/publications/parental-perceptions-of-childrensfinancial-socialization

28. Danes, S. M., \& Haberman, H. R. (2007) Teen financial knowledge, selfefficacy, and behaviour: A gendered view. Financial Counseling and Planning, 18(2), 48-60. Retrieved from https://files.eric.ed.gov/ fulltext/EJ1104367.pdf

29. Demirguc-Kunt, A., \& Klapper, L. (2012). Measuring financial inclusion: The global findex database (World Bank Policy Research Working Paper). https://doi.org/10.1596/1813-9450-6025

30. Dew, J. (2008). Debt change and marital satisfaction change in recently married couples. Family Relations, 57(1), 60-71. https://doi.org/10.1111/j.1741-3729.2007.00483.x

31. Eckel, C. C., \& Grossman, P. J. (2008). Men, women and risk aversion: Experimental evidence. In C. Plott, \& V. Smith (Eds.), Handbook of experimental economics results (Vol. 1, pp. 1061-1073). https://doi.org/10.1016/S1574-0722(07)00113-8

32. Edwards, R., Allen, M. W., \& Hayhoe, C. R. (2007). Financial attitudes and family communication about students' finances: The role of sex differences. Communication Reports, 20(2), 90-100. https://doi.org/10.1080/ 08934210701643719

33. Fernandes, D., Lynch, J. G., Jr., \& Netemeyer, R. G. (2014). Financial literacy, financial education, and downstream financial behaviours. Management Science, 60(8), 1861-1883. https://doi.org/10.1287/ mnsc.2013.1849

34. FINRA. (2003). NASD investor literacy research: Executive summary. Retrieved from https://www.finra.org/sites/default/files/InvestorDocument/p011459.pdf

35. Fonseca, R., Mullen, K. J., Zamarro, G., \& Zissimopoulos, J. (2012). What explains the gender gap in financial literacy? The role of household decision making. The Journal of Consumer Affairs, 46(1), 90-106. https://doi.org/10.1111/j.1745-6606.2011.01221.x

36. Fornero, E., \& Monticone, C. (2011). Financial literacy and pension plan participation in Italy. Journal of Pension Economics \& Finance, 10(4), 547-564. https://doi.org/10.1017/S1474747211000473

37. Fowler, F. J., Jr., \& Mangione, T. W. (Eds.). (1990). Standardized survey interviewing: Minimizing interviewer-related error (Vol. 18). https://doi.org/10.4135/9781412985925

38. Gamble, K. J., Boyle, P. A., Yu, L., \& Bennett, D. A. (2014). Aging and financial decision making. Management Science, 61(11), 2603-2610. https://doi.org/10.1287/mnsc.2014.2010

39. Goldsmith, R. E., \& Goldsmith, E. B. (2006). The effects of investment education on gender differences in financial knowledge. Journal of Personal Finance, 5(2), 55-69. Retrieved from https:/www.researchgate.net/ publication/268341254_The_Effects_of_Investment_Education_on_Gender_Di fferences_in_Financial_Knowledge

40. Hastings, J. S., Madrian, B. C., \& Skimmyhorn, W. L. (2013). Financial literacy, financial education, and economic outcomes. Annual Review of Economics, 5(1), 347-373. https://doi.org/10.1146/annurev-economics-082312125807 
41. Hilary, G., \& Hui, K. W. (2009). Does religion matter in corporate decision making in America? Journal of Financial Economics, 93(3), 455-473. https://doi.org/10.1016/j.jfineco.2008.10.001

42. Hilgert, M. A., Hogarth, J. M., \& Beverly, S. G. (2003). Household financial management: The connection between knowledge and behaviour. Federal Reserve Bulletin, 89, 309-322. Retrieved from https://www.federalreserve.gov/ pubs/bulletin/2003/0703lead.pdf

43. Hung, A., Parker, A. M., \& Yoong, J. (2009). Defining and measuring financial literacy (RAND Working Paper Series WR-708). https://doi.org/10.2139/ssrn.1498674

44. Huston, S. J. (2010). Measuring financial literacy. The Journal of Consumer Affairs, 44(2), 296-316. https://doi.org/10.1111/j.1745-6606.2010.01170.x

45. Johnson, E., \& Sherraden, M. S. (2007). From financial literacy to financial capability among youth. Journal of Sociology \& Social Welfare, 34(3), 119-145. Retrieved from https://scholarworks.wmich.edu/jssw/vol34/iss3/7/

46. Joo, S.-H., \& Grable, J. E. (2004). An exploratory framework of the determinants of financial satisfaction. Journal of Family and Economic Issues, 25(1), 25-50. https://doi.org/10.1023/B:JEEI.0000016722.37994.9f

47. Jorgensen, B. L. (2007). Financial literacy of college students: Parental and peer influences (Doctoral dissertation, Virginia Tech). Retrieved from https://vtechworks.lib.vt.edu/handle/10919/35407

48. Jorgensen, B. L., \& Savla, J. (2010). Financial literacy of young adults: The importance of parental socialization. Family Relations, 59(4), 465-478. https://doi.org/10.1111/j.1741-3729.2010.00616.x

49. Jump\$tart Coalition. (2017). National standards in $\mathrm{K}-12$ personal finance education (4th ed.). Retrieved from https://3yxm0a3wfgvh5wbo7lvyyl13wpengine.netdna-ssl.com/wp-content/uploads/2018/01/2017 NationalStandardsBook.pdf

50. Kim, J., LaTaillade, J., \& Kim, H. (2011). Family processes and adolescents' financial behaviors. Journal of Family and Economic Issues, 32(4), 668-679. https://doi.org/10.1007/s10834-011-9270-3

51. Kimiyaghalam, F., \& Safari, M. (2015). Review papers on definition of financial literacy and its measurement. SEGi Review, 8, 81-94. Retrieved from https://www.researchgate.net/publication/305754732_Review_papers _on_definition_of_financial_literacy_and_its_measurement

52. Klapper, L., Lusardi, A., \& van Oudheusden, P. (2015). Financial literacy around the world: Insights from the Standard \& Poor's ratings services global financial literacy survey (World Bank Report). Retrieved from http://nzz-filesprod.s3-website-eu-west-1.amazonaws.com/files/1/8/1/2015-

Finlit_paper_17_F3_SINGLES_1.18658181.pdf

53. Kramer, M. M. (2016). Financial literacy, confidence and financial advice seeking. Journal of Economic Behaviour \& Organization, 131, 198-217. https://doi.org/10.1016/j.jebo.2016.08.016

54. Lachance, M. J. (2012). Young adults' attitudes towards credit. International Journal of Consumer Studies, 36(5), 539-548. https://doi.org/10.1111/j.14706431.2012.01119.x

55. Lambert, E. G., Hogan, N. L., Jiang, S., Elechi, O. O., Benjamin, B., Morris, A., ... Dupuy, P. (2010). The relationship among distributive and procedural justice and correctional life satisfaction, burnout, and turnover intent: An exploratory study. Journal of Criminal Justice, 38(1), 7-16. https://doi.org/10.1016/j.jcrimjus.2009.11.002 
56. Longobardi, S., Pagliuca, M. M., \& Regoli, A. (2018). Can problem-solving attitudes explain the gender gap in financial literacy? Evidence from Italian students' data. Quality \& Quantity, 52(4), 1677-1705. https://doi.org/10.1007/s11135-017-0545-0

57. Lusardi, A. (2012). Numeracy, financial literacy, and financial decisionmaking (NBER Working Paper No. 17821). https://doi.org/10.3386/w17821

58. Lusardi, A. (2015). Financial literacy: Do people know the ABCs of finance? Public Understanding of Science, 24(3), 260-271. https://doi.org/10.1177/0963662514564516

59. Lusardi, A., \& Mitchell, O. S. (2007a). Baby boomer retirement security: The roles of planning, financial literacy, and housing wealth. Journal of Monetary Economics, 54(1), 205-224. https://doi.org/10.1016/j.jmoneco.2006.12.001

60. Lusardi, A., \& Mitchell, O. S. (2007b). Financial literacy and retirement planning: New evidence from the Rand American Life Panel (Michigan Retirement Research Center Research Paper No. WP 2007-157). https://doi.org/10.2139/ssrn.1095869

61. Lusardi, A., \& Mitchell, O. S. (2008). Planning and financial literacy: How do women fare? American Economic Review, 98(2), 413-417. https://doi.org/10.1257/aer.98.2.413

62. Lusardi, A., \& Mitchell, O. S. (2011a). Financial literacy around the world: An overview. Journal of Pension Economics \& Finance, 10(4), 497-508. https://doi.org/10.1017/S1474747211000448

63. Lusardi, A., \& Mitchell, O. S. (2011b). Financial literacy and retirement planning in the United States. Journal of Pension Economics \& Finance, 10(4), 509-525. https://doi.org/10.1017/S147474721100045X

64. Lusardi, A., \& Mitchell, O. S. (2011c). Financial literacy and planning: Implications for retirement wellbeing (NBER Working Paper No. 17078). https://doi.org/10.3386/w17078

65. Lusardi, A., \& Mitchell, O. S. (2014). The economic importance of financial literacy: Theory and evidence. Journal of Economic Literature, 52(1), 5-44. https://doi.org/10.1257/jel.52.1.5

66. Lusardi, A., \& Tufano, P. (2015). Debt literacy, financial experiences, and overindebtedness. Journal of Pension Economics \& Finance, 14(4), 332-368. https://doi.org/10.1017/S1474747215000232

67. Lusardi, A., \& Tufano, T. (2009). Teach workers about the perils of debt. Harvard Business Review, November, 22-24. Retrieved from https://hbr.org/2009/11/teach-workers-about-the-perils-of-debt

68. Lusardi, A., Mitchell, O. S., \& Curto, V. (2010). Financial literacy among the young. The Journal of Consumer Affairs, 44(2), 358-380. https://doi.org/10.1111/j.1745-6606.2010.01173.x

69. Mandell, L. (2006). Financial literacy: If it's so important, why isn't it improving? (Networks Financial Institute Policy Brief No. 2006-PB-08). https://doi.org/10.2139/ssrn.923557

70. Mandell, L. (2008). Financial literacy of high school students. In J. J. Xiao (Ed.), Handbook of consumer finance research (pp. 163-183). https://doi.org/10.1007/978-0-387-75734-6_10

71. Marcolin, S., \& Abraham, A. (2006). Financial literacy research: Current literature and future opportunities. In Conference Proceedings of the 3rd International Conference on Contemporary Business. Retrieved from https://ro.uow.edu.au/cgi/viewcontent.cgi?article=1233\&context=commpapers 
72. Markow, D., \& Bagnaschi, K. (2005). What American teens \& adults know about economics (National Council on Economic Education Research Paper). Retrieved from https://docplayer.net/131012-What-american-teens-adultsknow-about-economics.html

73. Monticone, C. (2010). How much does wealth matter in the acquisition of financial literacy? The Journal of Consumer Affairs, 44(2), 403-422. https://doi.org/10.1111/j.1745-6606.2010.01175.x

74. Moore, D. L. (2003). Survey of financial literacy in Washington State: Knowledge, behaviour, attitudes, and experiences (Washington State University, Social and Economic Sciences Research Center, Technical Report No. 03-39). Retrieved from https://www.researchgate.net/publication /265728242_Survey_of_Financial_Literacy_in_Washington_State_Knowledge _behavior_Attitudes_and_Experiences

75. Mottola, G. R. (2013). In our best interest: Women, financial literacy, and credit card behaviour. Numeracy, 6(2), 4. https://doi.org/10.5038/19364660.6.2.4

76. Murphy, A. J. (2005). Money, money, money: An exploratory study on the financial literacy of black college students. College Student Journal, 39(3), 478-489.

77. Murphy, J. L. (2013). Psychosocial factors and financial literacy. Social Security Bulletin, 73(1), 73-81. Retrieved from https://www.ssa.gov/ policy/docs/ssb/v73n1/v73n1p73.html

78. Noctor, M., Stoney, S., \& Stradling, R. (1992). Financial literacy: A discussion of concepts and competences of financial literacy and opportunities for its introduction into young people's learning (National Foundation for Educational Research).

79. O`Guinn, T. C., \& Faber, R. J. (1989). Compulsive buying: A phenomenological exploration. Journal of Consumer Research, 16(2), 147157. https://doi.org/10.1086/209204

80. OECD. (2005). Improving financial literacy: Analysis of issues and policies. https://doi.org/10.1787/9789264012578-en

81. OECD. (2014). PISA 2012 results: Students and money: Financial literacy skills for the 21st century (Vol. 6). https://doi.org/10.1787/9789264208094-en

82. OECD. (2016). G20/OECD INFE: Core competencies framework on financial literacy for adults. Retrieved from https://www.oecd.org/finance/CoreCompetencies-Framework-Adults.pdf

83. Pankow, D. (2012). Financial values, attitudes, and goals (NDSU Family Economic Specialist).

84. Porto, N., \& Xiao, J. J. (2016). Financial literacy overconfidence and financial advice seeking. Journal of Financial Service Professionals, 70(4). Retrieved from https://www.researchgate.net/publication/323856184_Financial_literacy _overconfidence_and_financial_advice_seeking

85. Renneboog, L., \& Spaenjers, C. (2009). Where angels fear to trade: The role of religion in household finance (Tilburg University Discussion Paper No. 2009-34). Retrieved from https://www.researchgate.net/publication/46434526 _Where_Angels_Fear_to_Trade_The_Role_of_Religion_in_Household_Finance

86. Robb, C. A., \& James, R. N., III. (2009). Associations between individual characteristics and financial knowledge among college students. Journal of Personal Finance, 8, 170-184. Retrieved from https://cutt.ly/CEgxuCw

87. Shim, S., Barber, B. L., Card, N. A., Xiao, J. J., \& Serido, J. (2010). Financial socialization of first-year college students: The roles of parents, work, and education. Journal of Youth and Adolescence, 39(12), 1457-1470. https://doi.org/10.1007/s10964-009-9432-x 
88. Shim, S., Serido, J., Tang, C., \& Card, N. (2015). Socialization processes and pathways to healthy financial development for emerging young adults. Journal of Applied Developmental Psychology, 38, 29-38. https://doi.org/10.1016/j.appdev.2015.01.002

89. Shu, T., Sulaeman, J., \& Yeung, P. E. (2012). Local religious beliefs and mutual fund risk-taking behaviors. Management Science, 58(10). https://doi.org/10.1287/mnsc. 1120.1525

90. Stolper, O. A., \& Walter, A. (2017). Financial literacy, financial advice, and financial behaviour. Journal of Business Economics, 87(5), 581-643. https://doi.org/10.1007/s11573-017-0853-9

91. Tezel, Z. (2015). Financial education for children and youth. In Z. Copur (Ed.), Handbook of research on behavioural finance and investment strategies: Decision making in the financial industry (pp.69-92). https://doi.org/10.4018/978-1-4666-7484-4.ch005

92. van Rooij, M., Lusardi, A., \& Alessie, R. (2011). Financial literacy and stock market participation. Journal of Financial Economics, 101(2), 449-472. https://doi.org/10.1016/j.jfineco.2011.03.006

93. van Rooij, M., Lusardi, A., \& Alessie, R. (2012). Financial literacy, retirement planning and household wealth. The Economic Journal, 122(560), 449-478. https://doi.org/10.1111/j.1468-0297.2012.02501.x

94. Volpe, R. P., Chen, H., \& Pavlicko, J. J. (1996). Personal investment literacy among college students: A survey. Financial Practice and Education, 6(2), 86-94. Retrieved from http://citeseerx.ist.psu.edu/viewdoc/download?doi $=10 \cdot 1 \cdot 1.476 .6325 \&$ rep $=$ rep $1 \&$ type $=$ pdf

95. Volpe, R. P., Kotel, J. E., \& Chen, H. (2002). A survey of investment literacy among online investors. Journal of Financial Counseling and Planning, 13(1), 1-13. https://u.osu.edu/hanna.1/financial-counseling-and-planning/13-2/volpe/

96. von Gaudecker, H.-M. (2015). How does household portfolio diversification vary with financial literacy and financial advice? The Journal of Finance, 70(2), 489-507. https://doi.org/10.1111/jofi.12231

97. Weaver, G. R., \& Agle, B. R. (2002). Religiosity and ethical behavior in organizations: A symbolic interactionist perspective. Academy of Management Review, 27(1), 77-97. https://doi.org/10.5465/amr.2002.5922390

98. Webley, P., \& Nyhus, E. K. (2006). Parents influence on children's future orientation and saving. Journal of Economic Psychology, 27(1), 140-164. https://doi.org/10.1016/j.joep.2005.06.016

99. Worthington, A. C. (2006). Predicting financial literacy in Australia. Financial Services Review, 15(1), 59-79. Retrieved from https://ro.uow.edu.au/commpapers/116/

100. Wuttke, E., \& Aprea, C. (2018). A situational judgement approach for measuring young adults' financial literacy. Empirische Pädagogik, 32(3-4), 272-292. Retrieved from https://www.wiwi.uni-frankfurt.de/publications/ publication/3833/A+Situational+Judgement+Approach+for+Measuring+Youn g+Adults $\% 2527+$ Financial+Literacy

101. Xiao, J. J., \& Porto, N. (2017). Financial education and financial satisfaction: Financial literacy, behaviour, and capability as mediators. International Journal of Bank Marketing, 35(5), 805-817. https://doi.org/10.1108/IJBM-012016-0009 


\section{BEHAVIOURAL FINANCE APPROACH TO FINANCIAL LITERACY}

\subsection{Introduction}

In the last twenty years, governments and authorities implemented a variety of policies to improve the financial literacy levels of citizens, promote investor education and support people's overall well-being.

Financial literacy can be considered as a mix of attitudes, awareness, behaviours, knowledge, and skills necessary to make sound financial decisions. It aims to improve appropriate use of financial products, awareness of investor rights and responsibilities, debt management financial inclusion, participation in securities markets, financial and retirement planning skills, financial well-being, informed savings, investment decision-making, risk awareness, and wealth accumulation.

Investor education and financial literacy programmes can help investors improving financial choices.

So far, however, conventional educational methods have mostly been used to increase knowledge of financial concepts, products, and markets, based on the assumption that poor financial decision-making was due to lack of knowledge and the expectation that better knowledge could eventually change behaviour.

Certain traditional policy approaches and initiatives were primarily based on the rational agent model to understand consumer behaviour.

The traditional economic model of human behaviour includes three main theoretical assumptions: unlimited rationality, unlimited willpower, and unlimited selfishness. However, in real life, people are not perfectly rational. At best, it is possible to assume bounded rationality.

The human mind is influenced by psychological factors, and people display limited (or even lack of) self-control. Voluntary work and philanthropy are counterexamples to the hypothesis of unlimited selfishness. In general, people care about social norms and expectations, and their preferences depend on social influences, such as peer pressure and herd behaviour, but also on motivations like the desire for social acceptance or status.

Psychological factors may prevent people from taking good financial choices. People have cognitive limitations, and they are affected by emotions, thus participants in educational programmes may not be able to understand, retain, or use the knowledge they gained in the classroom. Individuals may feel motivated at the end of a programme to start healthy financial habits, but there is no guarantee that they will maintain them over the long term. Even investors with high levels of financial literacy are prone to poor investment decisions made intuitively. These factors may induce people to take poor financial decisions, regardless of their level of financial literacy. 
While the traditional approach to financial literacy assumes rational behaviours and postulates how people should behave in theory, the behavioural one focuses on how people truly think and behave, drawing on empirical evidence from a range of social sciences, primarily economics and psychology, but also anthropology, marketing, pedagogy, and sociology.

The behavioural approach combines psychological insights into human behaviour to explain financial decision-making and how human behaviour deviates from (traditional economic) rationality.

In taking choices under uncertainty, individuals often employ mental shortcuts, known as heuristics, that help them in the decision-making process. Heuristics are mental shortcuts that people use, rules of thumb that drive deviations from rationality, creating distortions that are called "biases". Heuristics and biases are key concepts in behavioural economics because of their relevant influence on financial decision-making.

In addition to leading to suboptimal investment decisions, behavioural biases influence enrolment in educational initiatives and the way in which participants apprehend the conveyed knowledge.

Applying the behavioural approach can improve the effectiveness of investor education programmes and financial literacy initiatives.

It is important to bear in mind that not only individual investors and consumers, but also policymakers are prone to biases, thus the behavioural approach is useful to ensure that planned interventions have the desired effects and allow the public to review and control their actions and policies.

Public policy aims to change society not only through laws and regulations but also by using incentives and interventions to increase consumers' and investors' well-being, which depend on financial security. Thus, educational initiatives aiming at improving financial welfare can be considered effective policy interventions, but they also help addressing misalignments of investors and industry interests, with particular respect to information asymmetry, as a complement to regulation and supervision.

For these reasons, both the International Organization of Securities Commissions (IOSCO) and the Organization for Economic Co-operation and Development (OECD) have been actively engaged in advancing this policy.

In 2018, the OECD and IOSCO published a joint report titled "The Application of Behavioural Insights to Financial Literacy and Investor Education Programmes and Initiatives" (IOSCO \& OECD, 2018), presenting the results of complementary surveys among members of both IOSCO and OECD/International Network on Financial Education (OECD/INFE). In the remaining subchapter, we present the main findings of the report. 


\subsection{The IOSCO-OECD 2018 report on the application of behavioural insights to financial literacy and investor education programmes and initiatives}

The application of the behavioural approach to financial literacy and investor education programmes and initiatives is quite new and, as the IOSCO and OECD (2018) report points out, the degree to which respondent member organisations do apply it varies sensibly. Nevertheless, the report is useful in identifying practices and researches that are currently used by distinct authorities, and thus that can help policymakers, regulators, stakeholders, and in general who is interested in designing, developing, delivering, and eventually testing behaviourally informed financial literacy and investor education programmes.

The report shows how "behavioural insights" (BIs from now on) can be useful in guiding financial literacy initiatives, policies, and programmes.

IOSCO's Committee 8 on Retail Investors ("C8" from now on) ${ }^{2}$ surveyed IOSCO members ${ }^{3}$ about the resources they committed and their experiences in applying BIs to investor education initiatives. The INFE sent a questionnaire ${ }^{4}$ to its members $^{5}$ on the application of BIs to financial education and financial literacy policies and practices.

IOSCO's survey was on adult education initiatives, as IOSCO's focus is on retail investors.

The OECD/INFE survey, instead, collected initiatives for all age groups, based on OECD Principles and Best Practices for Financial Education and Awareness (OECD, 2005), stating that "People should be educated about financial matters as early as possible in their lives" (IOSCO \& OECD, 2018, p. 12).

The report starts recognising that traditional investor education and financial literacy initiatives and programmes have limitations, and that behavioural economics can help identifying the barriers that may prevent consumers and investors from making rational (or at least satisfactory) financial choices.

However, it is important to bear in mind that applying BIs does not ensure that people will eventually make better investment decisions or avoid frauds, even if it improves financial choices compared to applying only the traditional approach.

Thus, investor education aimed at increasing financial literacy cannot be considered a substitute for consumer and investor protection.

Nevertheless, OECD/INFE and IOSCO recognise that BIs help identifying (usually low-cost) simple methods to support financial

\footnotetext{
${ }^{2}$ For the list of IOSCO C8 members see Appendix G in the report (IOSCO \& OECD, 2018, pp. 121-122).

${ }^{3}$ Presented in the report in the Appendix E (IOSCO \& OECD, 2018, pp. 103-113). For the list of IOSCO members participating in the survey see Appendix A in the report (IOSCO \& OECD, 2018, pp. 83-84).

${ }_{5}^{4}$ Presented in the report in the Appendix F (IOSCO \& OECD, 2018, pp. 114-120).

${ }^{5}$ For the list of OECD/INFE members participating in the survey see Appendix A in the report (IOSCO \& OECD, 2018, p. 85).
} 
literacy and investor education programmes, providing innovative solutions, more in line with how people really behave.

Since there are several definitions of BIs, it is important to clarify that the OECD think them to be a discipline in a "family of three", together with behavioural economics and behavioural sciences in general, "which mix traditional economic strategies with insights from psychology, cognitive science and other social sciences to discover the many "irrational" factors that influence decision-making. [...] Behavioural insights aim at improving the welfare of citizens and consumers through policies and regulations that are formed based on empirically-tested results, derived using sound experimental methods" (OECD, as cited in IOSCO and OECD, 2018, p. 15).

BIs draw on a multidisciplinary approach — involving not only economics and psychology, but also anthropology, neurosciences, organisational studies, pedagogy, psychiatry, and sociology - and address several aspects of human life, such as decision-making, education, health, happiness, social behaviour, well-being, etc.

Since they can be applied in many fields such as education, incentives, and regulation, national and international regulatory and supervisory authorities are increasingly implementing BIs to design and apply more effective interventions.

It is worth underlying that BIs are more than "nudges" (Thaler and Sunstein, as cited in IOSCO and OECD, 2018). Even though nudging has proven to be a very effective behavioural technique in directing people towards better decisions (Thaler \& Sunstein, 2021), without explicitly prohibiting or limiting their choices, some policymakers could prefer avoiding such a paternalistic approach, even if "libertarian". Including many other techniques, BIs are particularly useful in place of nudges since they are not necessarily associated with specific intervention. Instead, BIs may even indicate that the best policy is not to take any measure at all (Lourenço, Ciriolo, Almeida, and Troussard, as cited in IOSCO and OECD, 2018).

The IOSCO-OECD report presents an interesting and useful literature review of relevant documents and reports on educational initiatives in the areas of investor education and financial literacy, using insights from the behavioural sciences ${ }^{6}$. Conducted between November 2016 and February 20177, the review identified 141 relevant reports and papers describing key BIs used to design public policy interventions, especially those aimed at achieving behaviour change.

\footnotetext{
${ }^{6}$ For the list of publications from OECD, IOSCO, IOSCO members, and OECD/INFE members on behavioural sciences and insights, related to investor education and financial literacy, see Appendix B in the report (IOSCO \& OECD, 2018, pp. 86-92). Appendix C instead presents the list of online resources and event mentioned in the report (IOSCO \& OECD, 2018, p. 93), while Appendix D (IOSCO \& OECD, 2018, pp. 94-102) all the literature review.

${ }^{7}$ IOSCO members were surveyed between December 2016 and January 2017 about their initiatives and programmes that incorporate applications of BIs. OECD/INFE members were interviewed later, between April 2017 and September 2017.
} 
Respondents not only described their approach to behavioural sciences, but also the resources devoted to developing behavioural applications, and the methods used to gain knowledge in these fields.

In what follows, we present some behavioural science research findings with potential applications to financial literacy and investor education initiatives.

IOSCO and OECD/INFE encourage their members to conduct research in behavioural economics to provide input to support the design, but also the implementation, of financial literacy and of investor education programmes.

In this respect, however, although the perceived need of promoting financial behaviour change was widespread among respondents, responses from both surveys showed varying degrees of application of BIs between members of IOSCO and OECD/INFE. Thus, it is important to distinguish between simple assessments of behaviour change and true applications of social science findings.

The IOSCO and OECD (2018) report presents the behavioural approaches used by survey respondents to change behaviour, as well as the initiatives and programmes of policymakers and practitioners in distinct member states, underlining the great variety of approaches used.

These approaches included behaviour-centred methods (e.g., deep interviews, prototyping, testing), experimental laboratory randomized control trials (RCTs), field experiments, and scientific models. Overall, RCTs and surveys have been identified as the methods that were mostly used by IOSCO and OECD/INFE member respondents to assess educational needs to be addressed with $\mathrm{BI}$ initiatives, but also to test and evaluate effectiveness in changing behaviour.

In addition, qualitative and quantitative surveys and literature reviews were tools often employed to inform the design of structures or initiatives to promote investor education or financial literacy.

On one side, respondents reported the use of behavioural principles and frameworks in the design of educational materials and initiatives to increase awareness of behavioural biases among investors and consumers, and help individuals develop desirable financial habits and skills. On the other side, it is important to highlight that only five respondents declared to apply scientific frameworks for financial literacy initiatives.

Furthermore, responses to the IOSCO and OECD/INFE surveys showed different understanding of what behaviourally informed interventions are, resulting in multiple strategies depending on how BIs are integrated into an existing educational framework.

The report identified three main approaches: 1) directly helping individuals overcome one or more behavioural biases; 2) providing information to consumers and investors about behavioural biases, as well as appropriate decision-making practices, and 3) using psychological 
factors (e.g., attitudes, beliefs, behaviours) in evaluating the impact of educational initiatives.

Using experiential learning techniques seems to be useful in simplifying educational content, to be easier to comprehend, and in conveying information in more fun and familiar ways.

The report shows that it is advisable to apply BIs not only to traditional educational approaches, but also to insert them into apps, documents, and interactive games.

Applying BIs helped IOSCO and OECD/INFE members both to develop effective campaigns and to inform their regulatory activities, but also to develop new rules, studying and analysing the impacts of distinct disclosure formats, consumer experiences, perceptions, and understandings with financial products.

\subsection{Applications of BIs to financial literacy/investor education programmes in Italy}

The IOSCO and OECD (2018) report mentions the Italian experiences in applying BIs to financial literacy and investor education programmes.

We report here some of them, as well as additional ones that we think to be particularly interesting and useful. Of course, this should be thought as a comprehensive list of all the numerous initiatives carried out in Italy.

In this respect, the report often cites the initiatives of CONSOB ("Commissione Nazionale per le Società e la Borsa", i.e., National Commissions for Companies and the Stock Exchange), which is the public authority responsible for regulating the Italian financial markets.

In an interesting report (Linciano, as cited in IOSCO and OECD, 2018) CONSOB shows how biases and heuristics influence choices related to investments, leading to low participation of retail investors in the stock market, but also to misperceptions of the risk-return relationship, poor diversification, and, for whom instead invest in the stock market, excessive trading. The CONSOB report also shows that behaviourally informed initiatives, together with a better disclosure related to investment products and financial advice, can improve financial literacy, and help investors make better investment decisions.

In another study (Linciano and Soccorso, as cited in IOSCO and OECD, 2018), CONSOB analysed 20 markets in financial instruments directive (MiFID) questionnaires used by Italian banks to investigate how they assessed investors' risk tolerance, finding several limitations. The analysed MiFID questionnaires often asked questions on investment experience and knowledge relying on self-evaluation. In addition, they did not assess important notions related to diversification or risk-return relationship, risk attitude was not independently measured and 
questions asked to measure risk tolerance did not control for cognitive and behavioural biases such as overconfidence that may lead to a biased perception of risk, typically underestimating it.

The survey also found that complex (or ambiguous) language was sometimes used and that banks were not training their staff about how behavioural biases could negatively affect the administration of questionnaires and the associated answers.

In this regard, to spread knowledge about behavioural biases and how to correct them, CONSOB inserted the explanation of some of them in the educational area of its institutional website, as well as tips for avoiding them, or at least to reduce their negative effects. Not only the content but also the design of the investor education website area was informed by behavioural insights. This was also due to CONSOB's belief, based on evidence, that online behaviour should be treated with care.

To better engage and educate investors to the typical and frequent errors committed while investing, in collaboration with the University of Trento, CONSOB developed an interactive game to explain the effects of cognitive biases on investment choices, based on a learning-by-doing approach that provides personalized feedback for testing exposure to behavioural biases and attitude toward risk ${ }^{8}$.

Behaviourally informed regulations should consider that online decision-making could be influenced by biases and lead to suboptimal or inappropriate investment decisions. Thus, it is possible to require investors to read mandatory educational materials or to answer questionnaires in order to test their true understanding of financial products' features and risks.

Using a survey to assess the effectiveness of these mechanisms, CONSOB found for example that the primary users of crowdfunding platforms were sophisticated investors and venture capital funds that however perceived the disclosure requirements of the rule as unimportant. A possible explanation is that sophisticated investors and institutional investors may be overconfident and not fully understand the importance of mechanisms designed to reduce the negative effects of behavioural biases.

Based on this evidence, CONSOB conducted a behaviourally informed experiment to analyse how investors evaluate different risk-return representations (frames) in terms of information content, but also complexity, and usefulness. It tested four different return-cost frames based on four investment products proposed in the Italian market: an outstanding structured bond, a newly issued structured bond and two equities. The results showed that individuals' financial knowledge, investment habits and personal traits could reinforce framing

\footnotetext{
${ }^{8}$ See http://edufingame.consob.it/game
} 
effects, leading to biased risk perception and investment decisions. It is interesting to stress that the respondents were experienced investors ${ }^{9}$. The experiment found that investors with a higher level of financial literacy were subject to the disposition effect - i.e., the disposition to sell winning investments too early, while keeping losing ones in the portfolio for too long - and other cognitive biases.

Thus, a conclusion of the study was that simplifying financial disclosure was not sufficient to ensure unbiased investment decisions and correct risk perception. This result shows that an optimal degree of financial disclosure may not exist in general, and a "one-size-fits-all" approach may not effectively work to achieve a suitable level of investor protection.

The collective working paper published by CONSOB (Linciano and Soccorso, as cited in IOSCO and OECD, 2018) - in the occasion of its participation in the 2017 World Investor Week (October 2-8) sponsored by IOSCO - includes essays gathering distinct views on how approaches from behavioural finance, cognitive psychology, neuroscience, pedagogy, and sociology can improve educational programmes audience targeting and delivery, also through the elicitation of personal attitudes. They have the goal to provide insights into methods and tools that can favour effective design and delivery of educational programmes, through coordination among the academia and the involved stakeholders.

CONSOB is also involved in an experimental study - in cooperation with the Centre for Experimental Economics (CESARE) of LUISS in Rome and the University of Genoa - aiming at evaluating how robot advice affects investors' investment choices, that is whether (and to what extent) individuals' decisions differ in a digital environment compared to the traditional physical channel (e.g., through banks), and how to protect investors using these tools. In particular, participants in the experiment have to evaluate both a computerised algorithm and a human consultant investment proposal - that actually propose the same investment advice - and eventually make an investment decision.

Not only CONSOB of course, but also other institutions are proposing tools to improve knowledge on behavioural biases and how to face them. An interesting example is the Bank of Italy's financial education website (launched in 2019) "L'economia per tutti" (literally, "Economics for everyone") with videos on biases and heuristics (https://economiapertutti.bancaditalia.it/video/index.html) that were designed and recorded in collaboration with the Ca' Foscari University of Venice ${ }^{10}$.

\footnotetext{
${ }^{9}$ Respondents were 254 experienced investors, randomly selected from a geographically stratified sample of Italian banks' customers from 8 cities.

${ }^{10}$ Under the supervision of one of the authors of this book, Enrico Maria Cervellati.
} 


\subsection{Debiasing techniques}

The above-mentioned review of BIs and of their applications to the areas of investor education and financial literacy was aimed at collecting best practice to eliminate, or at least mitigate, the negative effects of behavioural biases ${ }^{11}$ — the so-called "debiasing" process — on financial decision-making.

Debiasing strategies - designed to improve investors' financial literacy have been identified using educational approaches, experiential learning techniques, and simulation systems - can be classified into two main categories (Soll, Milkman, and Payne, as cited in IOSCO and OECD, 2018), depending on the object of intervention: the decisionmaker or the environment. The decision-maker is the consumer or the investor, while by environment the report means the decision-making environment.

The first approach is to provide knowledge that enables consumers and investors to analyse financial issues more effectively, take more informed decisions, and learn techniques to minimize the negative effects of behavioural biases. As mentioned, in this respect, traditional teaching techniques may be inadequate to convey the necessary financial content and debiasing techniques. Traditional learning programmes may be too short, too boring, or difficult to understand.

Teaching methods outside the classroom, such as simulation systems and experiential learning, seem instead to decrease the presence of biases and improve participation ${ }^{12}$.

Emotional engagement is a powerful tool to keep learners' attention and deliver educational messages through soap operas, movies, and interactive programmes.

Of course, also monetary incentives (e.g., payment for attendance) are successful in increasing uptake of financial literacy programmes, even if they appear to be short-lived, that is benefits tend to fade away when the monetary incentive is removed.

Improving numeracy skills is also important since poor math skills are linked to decision errors, such as those caused by framing effects, misunderstanding of negative financial risk, and ratio bias (Peters, Västfjäll, Slovic, Mertz, Mazzocco, and Dickert, as cited in IOSCO and OECD, 2018; Ghazal, Cokely, and Retamero, as cited in IOSCO and OECD, 2018; Newall, as cited in IOSCO and OECD, 2018) ${ }^{13}$.

\footnotetext{
${ }^{11}$ Since the scientific literature commonly uses the word "bias" to express both the process and the outcome, the IOSCO and OECD (2018) report adopts the term behavioural bias with the same general meaning. However, to be more precise, applying heuristics in the decision-making process may eventually lead to biases. This is why they are called "heuristic-driven biases".

${ }^{12}$ Morewedge, Yoon, Scopelliti, Symborski, Korris, and Kassam (as cited in IOSCO and OECD, 2018) verified the immediate (post-test) and long-term (after one year) debiasing effects of both a game and an instructional video on heuristics, finding that both training methods significantly reduced the effects of six different behavioural biases in both the post-test (immediate) and follow-up (long-run) assessments. These training techniques may be easily inserted into financial literacy and investor education programmes.

${ }^{13}$ In this respect, quantitative methods (e.g., econometric analyses and simulation models) are powerful tools for decision-making, elaborating forecasts, and debiasing judgements (Soll et al., as cited in IOSCO and OECD, 2018). However, they may be too complex for basic educational programmes; thus, it is important to try to simplify as much as possible to be effective.
} 
To reduce the negative impact of behavioural biases it is important to first identify and evaluate the cognitive biases of the target audience of educational programmes. In this respect, segmentation based on socio-demographics or psychographic profiling (i.e., classifying individuals into groups according to their attitudes, beliefs, personality, and values) seems to be useful to design educational programmes that are customised on the target audience and effective against its specific behavioural biases (Ackert and Deaves, as cited in IOSCO and OECD, 2018).

While illustrating behavioural biases, their effects, and how to mitigate (or even try to avoid) them is a starting point, teaching decision rules on how to deal with them, accompanied by examples, seems to help participants to really apply the concepts learned during the educational programmes into practice. The reason for this evidence is that doing so enables participants to identify the real-file situations in which they can apply the acquired knowledge, thus motivating them (Larrick, Morgan, and Nisbett, as cited in IOSCO and OECD, 2018).

Since financial behaviour depends on psychological attributes more than on knowledge or skills, it is vital to avoid relying on simple passive learning and instead switch to active mode using, for example, "norm manipulation" - i.e., directing people to take specific actions (e.g., save more) with slogans or rules of thumb - and face-to-face crisis counselling (De Meza, Irlenbusch, and Reyniers, as cited in IOSCO and OECD, 2018) ${ }^{14}$.

Both the scientific community and public institutions conducted experiments providing participants both knowledge and advice to reduce the negative effects of behavioural biases on both their financial behaviours and decisions.

To test debiasing techniques to overcome "narrow thinking" - i.e., think in a too focused way - for example, behavioural economists and psychologists use experiments encouraging people to take a broader view of the problem at hand, but also looking at it from different angles.

One approach is to identify all the goals to be achieved by the decision in question, but one at a time, to reduce complexity, since considering them all at once may be overwhelming. Instead, addressing goals one at a time allows to produce valuable alternatives and increases the chances of taking a good decision, a process called "value-focused brainstorming" (Keeney, as cited in IOSCO and OECD, 2018).

To deal with confirmation bias, over-optimism and overconfidence, people may find it useful to think why they overestimate their probability of success in a specific task (e.g., prediction), or they can

\footnotetext{
${ }^{14}$ This is the report resulting from a literature review on the likely impact of financial capability initiatives on behavioural outcomes, commissioned by UK Financial Services Authority (FSA) (that became Financial Conduct Authority (FCA) in 2013). The report discusses six debiasing approaches - 1) consider-theopposite, 2) accountability, 3) training in rules, 4) training in representations, 5) voluntary cooling-offperiods, and 6) group decisions - under the five components proposed in the Financial Capability Survey Baseline (FSA, 2006).
} 
apply the "prospective hindsight technique", that consists of projecting themselves into the future, hypothesize a failure scenario (instead of a successful one), and then analyse possible causes of the negative scenario. This approach is useful in identifying and recognising potential causal paths that typically do not come to mind in foresight, since over-optimism leads to see the future with rose-coloured glasses (Koriat, Lichtenstein, and Fischhoff, as cited in IOSCO and OECD, 2018; Mitchell, Russo, and Pennington, as cited in IOSCO and OECD, 2018).

Explicit written warnings resulted effective in reducing overconfidence among financial professionals (Kaustia and Perttula, as cited in IOSCO and OECD, 2018).

Educational programmes that sent electronic notifications to participants both before and after simulated investment decisions have proven to be successful in reducing such as ambiguity, the disposition effect, framing effects, and representativeness (Döbrich, Wollersheim, Spörrle, and Welpe, as cited in IOSCO and OECD, 2018).

Simulations are learning resources that have proven to be particularly useful since they are based on direct experience and being task-based. They are a less misrepresentative alternative to surveys in assessing risk preferences (Eckel and Carpenter, as cited in IOSCO and OECD, 2018).

Respondents to both the IOSCO and OECD/INFE surveys used experiments including commitment devices, mental accounting mechanisms, and text reminders to increase savings, especially for low-income individuals.

Other applications of BIs to financial literacy programmes (e.g., one-on-one counselling, rule-of-thumb training, etc.), not only increased participants' self-efficacy, but were also useful in debiasing, addressing behavioural issues such as forgetfulness, lack of self-control, and procrastination.

Behaviours are the result of individual choices, but also of the decision-making environment. When individuals' behavioural biases are hard to avoid or mitigate, an alternative approach is to modify the environment in which choices are taken, encouraging desired behaviours, or finding ways to make biases irrelevant, instead of trying to change the decision-makers' behaviours. In this respect, designed solutions are often based on automatic processes of judgement.

It is possible to modify the decision environment by either providing economic incentives or using so-called "choice architecture" techniques to nudge individuals to certain choices (or non-choices) that are considered better outcomes for them.

Economic incentives can be either monetary, such as subsidies, fines, and bonuses, or non-monetary, like conveying social norms and accountability, and represent traditional tools to alter the decisionmaking environment. 
Incentives are used to encourage wise behaviours and to discourage undesirable ones. As an example, both types of incentives have been used to increase savings. Savings-linked rewards bring a monetary incentive providing an attractive opportunity for learning through action. Companies matching their employee retirement contributions use monetary incentives to favour retirement savings. Instead, non-monetary incentives such as introducing accountability and conveying social norms (e.g., peer pressure) are often used to favour group saving behaviour.

Of course, monetary, and non-monetary incentives can be used together. An example is represented by companies using both employee contribution matching, and automatic enrolment to increase savings for retirement.

About altering the decision-making environment, the report also refers to "nudging", which is probably the most well-known form of "choice architecture" based on automatic decision-making processes, such as automatic enrolments and use of default rules that have proven to be successful in increasing participation in retirement savings plans (Thaler and Sunstein, as cited in IOSCO and OECD, 2018).

Choice architecture interventions are designed to offer choices or alter the decision-making process to influence behaviour for good.

With respect to financial literacy, nudges can be applied to encourage good financial behaviours such as saving money and investing wisely.

Although nudges have proven to be able to change the decisionmaking environment, an important issue remains unsolved, that is that the single individual - either the consumer or the investor - still has to take a decision to change behaviour. Properly manipulating the decisionmaking environment achieves the result of changing the outcomes of behaviours, without however changing people's minds, approaches and intentions.

Nudges are attractive for public makers since they typically offer quick and usually low-cost solutions to the problem while maintaining (at least apparently) citizens' freedom of choice. However, institutions may encounter limitations trying to apply these techniques to financial literacy programmes. This is why it is important to investigate alternative approaches, mentioned in the IOSCO and OECD (2018). The next subchapter reports some of them.

\subsection{Approaches for applying behavioural insights}

Based on the research and on the experiences of respondents to the IOSCO and OECD/INFE surveys, it is possible to propose several suggestions for policymakers, regulators, and any other organisations or institutions who are considering applying BIs to financial education programmes and initiatives aimed at investors and consumers. 
In summary, these suggestions (IOSCO \& OECD, 2018, p. 8) are to:

1. establish a concrete understanding of the problem;

2. design the intervention taking the context into account;

3. start small;

4. evaluate rigorously;

5. interact, learn, and keep track;

6. create thought leadership;

7. consider combining traditional approaches and those based on behavioural insights;

8. review programmes/initiatives regularly.

The eight above-mentioned suggestions are discussed in detail in what follows.

The first is to "establish a concrete understanding of the problem" refers to a very important issue related to the so-called "action bias", that is the natural human tendency toward action rather than inaction and consists in responding with action as an automatic (default) reaction, even without a solid rationale in support of acting.

While often beneficial, there are situations in which people feel compelled to act, even if there is no evidence that action will actually lead to better outcomes, compared to doing nothing.

From a policymaking point of view, it is important to achieve effective solutions avoiding action bias, waiting to design solutions or hurry to execution before carefully assessing the problem at hand.

It is thus crucial to analyse (both qualitatively and quantitatively) previous experiences in addressing the specific problem, but also try to detect the main behavioural biases that can influence individuals' decisions, and understand if it is better to act, maybe using BIs, rather than do nothing.

In case a behavioural change is thought to be necessary, it is important to define it with precision.

The second is to "design the intervention taking the context into account", that is to be aware of all people involved in the situation at hand.

Counsellors, managers, potential participants, staff, etc., can provide valuable insights or even just information about the situation.

It is thus important to spend some time analysing the problem context and decision environment.

Assumptions on individuals' responses to policy interventions are potentially misleading since people do not always act in line with the attitudes, beliefs, and intentions (the so-called "intention-behaviour gap").

In adapting or replicating previous actions, it is vital to examine the specific context, methodology, scope, evidence of impact, but also limitations, and compare them with the specific situation at hand, underlining both analogies and differences, that is the peculiarities of the particular environment and situation to be managed, compared to past experiences, including different needs of the specific audience to which the intervention is intended. 
The third is to "start small". The real world is more complex than theory would suggest. Thus, even after careful analysis and design, applying BIs is challenging because the success of an intervention depends on many factors, some of which may be uncontrollable or overlooked and can compromised it.

Thus, especially for new interventions (but also for replications of previous ones), it is advisable to start with a small-scale pilot phase using field tests ${ }^{15}$ to collect feedback and eventually adjust.

After this phase, it is nevertheless important to continue listening to participants, as unexpected new and different issues arise as the scale of the projects expands.

The fourth is to evaluate interventions rigorously, through experiments (e.g., using $\mathrm{RCTs})^{16}$, or quasi-experiments ${ }^{17}$, to analyse the audience responses, compared to a control group.

Testing and evaluating the intended target groups' responses is important to gather accurate and usable evidence.

When an intervention is designed for wide-ranging benefit, it is important to approach a distinct target group from different geographical areas.

In general, it is crucial to evaluate interventions on a continuous basis, using survey instruments and outcome indicators such as those developed by the OECD and the World Bank ${ }^{18}$ to encourage international comparisons and meta-analyses.

The fifth is to "interact, learn and keep track" because the application of the behavioural approach to financial literacy and investor education is quite new.

Thus, it is important to gather knowledge on previous experiences, not only through cases available from the literature, but with events, networks, and partnerships with other institutions that already used BIs as well as with research centres and universities to better develop scientific understanding.

Then, it is also important to share within the organisation ideas for behavioural applications and initiatives, as well as the results of the evaluation process, irrespectively of their relative success. Successful approaches, once identified, form the base for future interventions.

In the implementation phase, it is crucial to identify the stakeholders that can help to build credibility and trust with the target audiences and to scale up the educational message.

The sixth is to "create thought leadership", one of the goals of the IOSCO and OECD (2018) report, that is to provide public authorities, but also private financial institutions, with updated information on

\footnotetext{
${ }^{15}$ Different testing methodologies should be used, such as: A/B testing, multiple prototypes, one-on-one, etc. (IOSCO \& OECD, 2018, p. 79).

${ }^{16}$ RCTs were not developed by behavioural economists, but their application to studies of BIs is an innovation in the evaluation of social policies.

${ }^{17}$ RCTs allow establishing causal relationships between the behavioural insights and the outcomes (Financial Literacy \& Education Russia Trust Fund, 2013a, pp. 25-26).

${ }_{18}$ For examples of questions and indicators, see OECD/INFE (2016), Financial Literacy \& Education Russia Trust Fund (2013b).
} 
the benefits of applying BIs to financial literacy and investors education programmes.

Before applying BIs, it is then important to review already tested behavioural frameworks to address biases, then develop new approaches.

The seventh is to "consider combining traditional approaches and those based on behavioural insights". Applying BIs is not a substitute, but a complement to traditional methods for financial literacy and investor education programmes.

Combining BIs and cognitive-based approaches builds on both the automatic (system 1) and the analytical (system 2) mental systems of the brain, thus increasing the chances of obtaining behaviour change.

Behaviourally informed regulation may be insufficient to solve critical public policy issues, thus regulators may think about it as a supplement to other stronger interventions, such as bans, subsidies, and taxes.

The eighth is to "review programmes/initiatives regularly". Existing traditional educational methods and materials should be evaluated using a BIs lens, because they may not consider cognitive biases that may hinder learning, thus wasting resources.

To do so, it is crucial to examine all components of a specific intervention from a behavioural perspective and keep examining them on a regular basis.

\section{References}

1. Financial Literacy \& Education Russia Trust Fund. (2013a). A toolkit for the evaluation of financial capability programmes in low-and middle-income countries. Retrieved from https://www.financialcapability.gov.au /files/research_toolkit-for-evaluation-of-financial-capability-programs-in-lowand-middle-income-countries-summary.pdf

2. Financial Literacy \& Education Russia Trust Fund. (2013b). Evaluating financial education programmes: OECD/INFE stocktake and framework. Retrieved from https://www.oecd.org/daf/fin/financial-education/TrustFund2013_ OECD_INFE_Evaluating_Fin_Ed_Programmmes.pdf

3. Financial Services Authority (FSA). (2006). Levels of financial capability in the UK: Results of a baseline survey. Retrieved from https://financialhealthexchange.org.uk/wp-content/uploads/2015/11/Levels-offinancial-capability-in-the-UK-Results-of-a-basline-survey.pdf

4. IOSCO, \& OECD. (2018). The application of behavioural insights to financial literacy and investor education programmes and initiatives. Retrieved from https://www.oecd.org/finance/The-Application-of-Behavioural-Insights-to-

Financial-Literacy-and-Investor-Education-Programmes-and-Initiatives.pdf

5. OECD. (2005). Recommendation on principles and best practices for financial education and awareness. Retrieved from https://www.oecd.org/ finance/financial-education/35108560.pdf

6. OECD/INFE. (2016). OECD/INFE international survey of adult financial literacy competencies. Retrieved from https://www.oecd.org/finance/oecd-infesurvey-adult-financial-literacy-competencies.htm

7. Thaler, R. H., \& Sunstein, C. R. (2021). Nudge: The final edition. New York, NY: Penguin Books. 


\subsection{Introduction}

As mentioned in Chapter 2, the behavioural approach to financial literacy is relatively recent and still in development (IOSCO \& OECD, 2018; Shefrin, 2019).

Studies in the literature support the existence of a relationship between financial literacy and financial behaviour.

Higher levels of financial literacy appear to be related to better management of credit cards (Disney \& Gathergood, 2013), prudent financial behaviour such as paying bills on time, tracking expenses, and budgeting (Hilgert, Hogarth, \& Beverly, 2003), wiser investments in the stock market (van Rooij, Lusardi, \& Alessie, 2011), improved long-term wealth management (Stango \& Zinman, 2009), increased retirement saving (Lusardi \& Mitchell, 2011), and better debt management (Lusardi, Schneider, \& Tufano, 2015).

For decades, however, financial literacy has primarily been conceived as a way of conveying information about fundamental financial concepts.

Most recent contributions to the literature show this approach does not automatically translate into behavioural changes (Duflo \& Saez, 2003; Lyons, Chang, \& Scherpf, 2006; Lusardi, 2008; Garcia, 2013).

While in some cases providing adequate information has promoted changes in people's financial behaviour (Barberis \& Thaler, 2003; Shefrin, 2019), in others it has not (Bernheim, Garrett, \& Maki, 2005).

Thus, in addition to improving financial literacy, public interventions should also help individuals change their behaviour so that they can internalize the information received through financial literacy programmes and use it in everyday life (Berti, Bombi, \& Duveen, 1988).

While cognitive issues matter in financial affairs, personality matters greatly too (Statman \& Wood, 2004; Borghans, Duckworth, Heckman, \& ter Weel, 2008; Pan \& Statman, 2013). Personality influences all choices, including financial ones.

Probably the most recognised theory of personalities is the so-called "Big Five", referring to the main personality traits proposed by McCrae and Costa (1987): openness to experiences, conscientiousness, extraversion, agreeableness, and neuroticism (also called emotional stability) ${ }^{19}$.

This personality theory is also known as the five factor model (FFM) and we will use this alternative way of calling it, also to distinguish it from what we have called "Big Five" questions used to measure financial literacy.

\footnotetext{
${ }^{19}$ For ease of recall, the initials of the five personality traits form the acronym OCEAN.
} 
Openness (to experiences) captures the disposition of an individual to seek cultural and thought stimuli external to their ordinary context. A subject with a high degree of openness will be curious, original, and creative.

Conscientiousness measures accuracy, precision, and reliability that the individual is oriented to offer through his conduct, as well as the will to succeed and his perseverance. A conscientious person will be organised, responsible and precise.

Extraversion captures the degree of activation, trust, and enthusiasm in behaviours. An extraverted person will be enthusiastic, talkative, and expansive.

Agreeableness relates to the quantity and quality of the positive interpersonal relationships that the individual undertakes. An agreeable individual will be grateful, generous, oriented to take care of, welcome and inspire confidence in others.

Neuroticism (emotional stability) measures the degree of resistance to emotional stress. A neurotic person will be anxious, touchy, and unstable, easily disturbed, and annoyed.

The FFM is probably the most used personality model in economics and finance since it encompasses a wide range of personalities, describing most of them. Previous studies found that conscientiousness is related to life achievements, marital stability, and longevity (Duckworth $\&$ Weir, 2011). With respect to others, conscientious people accumulate more wealth as they save more of their income and spend less. They neither act impulsively nor spend too much buying things they do not need.

Personality and related behaviours are partly heritable. Cesarini, Dawes, Johannesson, Lichtenstein, and Wallace (2009) found in studies of identical and fraternal twins that genetic factors account for twenty to thirty percent of the variation in risk tolerance among people. Cronqvist and Siegel (2014) found that genetic factors are associated with propensity to save. Borghans et al. (2008) argue that cognitive skills matter as much in economic and social success as personality and motivation. They also showed that personality is only partially heritable and is more sensitive than cognitive abilities to environmental influences, such as those of parents and teachers. Kuhnen and Chiao (2009) found that the short version of the serotonin transporter gene is associated with conservative portfolio allocations and Kuhnen and Knutson (2011) showed that people carrying the short version of the gene are more likely to avoid risk and complexity in financial choices, invest less in stocks, being less engaged in making investment decisions, and have fewer lines of credit.

Through a survey of more than 2,500 people, Pan and Statman (2013) analyse the links between the five personality traits, risk tolerance and other investor propensities.

In particular, the authors investigate life satisfaction and overconfidence, but also several propensities such as the propensity to 
attribute success to luck or ability, the propensity to maximization, the regret proneness ${ }^{20}$.

The authors find that personality traits influence risk tolerance, even after accounting for age and gender. Risk tolerance is high among people with high levels of extraversion and openness, relatively low among those with high levels of conscientiousness, and uncorrelated with agreeableness.

Investors have two fundamental objectives: downside protection and upside potential. Some people prefer protection in case of downside; others look for potential in case of upside. This holds not only for investments but also for professions and seems to be explained, at least in part, by different personalities. People who favour downside protection prefer professions and portfolios that offer even modest, but secure, wealth while those who cultivate upside potential favour professions and portfolios that offer a chance, albeit small of great wealth.

With respect to behavioural aspects, Pan and Statman (2013) find that overconfidence is high among respondents with relative levels of extraversion but relatively low among those with high levels of agreeableness.

The propensity to regret is low among people with high levels of extraversion but high among people with high levels of conscientiousness. The tendency of people with high levels of conscientiousness to attribute success to ability exposes them to regret. Thus, propensity to regret is particularly high among people with high levels of conscientiousness.

The propensity to trust is high among people with high levels of agreeableness, extraversion, and openness, but low among people with high levels of conscientiousness.

Life satisfaction is high among people with high levels of extraversion, but low among people with high levels of openness.

A high propensity to maximize is positively correlated with extraversion and conscientiousness, but negatively with openness and agreeableness.

The authors also find that some personality traits were correlated: conscientiousness was negatively correlated with the other three factors, but agreeableness was positively correlated with extraversion and openness. The relationship between extraversion and openness was instead not statistically significant.

This chapter aims to obtain a more comprehensive understanding of financial behaviour by combining the above-mentioned perspectives, that is behavioural aspects, individual propensities and personality traits that may influence people's financial behaviour.

\footnotetext{
${ }^{20}$ In a companion article (Pan \& Statman, 2012), the authors analyse these relationships more in-depth, not considering however personality traits. The authors find that risk tolerance increases with trust, but also with overconfidence, and propensity for maximisation. They also find that gender and age play a role in connecting behavioural aspects to individual propensities. For example, with respect to women, men display higher overconfidence (Barber \& Odean, 2001), higher risk tolerance, a lower propensity for regret, a higher propensity for maximisation, and a lower propensity to attribute success to luck. Furthermore, compared to younger people, older people exhibit less risk tolerance, a lower propensity for maximisation, and a higher propensity for trust.
} 


\subsection{Data and methodology}

Our research sample is composed of Italian respondents aged 18 to 93 . The data were gathered via a web-based questionnaire administered from March to May 2019, with the sample selected randomly. We collected 5,600 questionnaires, and after cleaning up missing values, the final sample contained 5,278 respondents.

We measure financial literacy according to the methodology used by Lusardi and Mitchell (2011), that is using the "Big Five" questions from Global Financial Literacy Excellence Center (GFLEC) (see Table 3).

Table 3. Financial literacy questions

\begin{tabular}{|c|c|}
\hline Questions & Answers \\
\hline $\begin{array}{l}\text { 1) Suppose you had } \$ 100 \text { in a savings account and the } \\
\text { interest rate was } 2 \% \text { per year. After } 5 \text { years, how much } \\
\text { do you think you would have in the account if you left } \\
\text { the money to grow? }\end{array}$ & $\begin{array}{l}\text { 1. More than } \$ 102 \\
\text { 2. Exactly } \$ 102 \\
\text { 3. Less than } \$ 102 \\
\text { 98. Do not know } \\
\text { 99. Refuse to answer }\end{array}$ \\
\hline $\begin{array}{l}2 \text { ) Imagine that the interest rate on your savings } \\
\text { account was } 1 \% \text { per year and inflation was } 2 \% \text { per year. } \\
\text { After } 1 \text { year, how much would you be able to buy with } \\
\text { the money in this account? }\end{array}$ & $\begin{array}{l}\text { 1. More than today } \\
\text { 2. Exactly the same } \\
\text { 3. Less than today } \\
\text { 98. Do not know } \\
\text { 99. Refuse to answer }\end{array}$ \\
\hline $\begin{array}{l}\text { 3) Please tell me whether this statement is true or false: } \\
\text { "Buying a single company's stock usually provides a } \\
\text { safer return than a stock mutual fund". }\end{array}$ & $\begin{array}{l}\text { 1. True } \\
\text { 2. False } \\
\text { 98. Do not know } \\
\text { 99. Refuse to answer }\end{array}$ \\
\hline $\begin{array}{l}\text { 4) Please tell me whether this statement is true or false: } \\
\text { "A } 15 \text {-year mortgage typically requires higher monthly } \\
\text { payments than a } 30 \text {-year mortgage, but the total } \\
\text { interest over the life of the loan will be less". }\end{array}$ & $\begin{array}{l}\text { 1. True } \\
\text { 2. False } \\
\text { 98. Do not know } \\
\text { 99. Refuse to answer }\end{array}$ \\
\hline $\begin{array}{l}\text { 5) If interest rates rise, what typically happens to bond } \\
\text { prices? }\end{array}$ & $\begin{array}{l}\text { 1. They fall } \\
\text { 2. They rise } \\
\text { 3. They stay the same } \\
\text { 4. There is no relationship } \\
\text { between bond prices and } \\
\text { interest rates } \\
\text { 98. Do not know } \\
\text { 99. Refuse to answer }\end{array}$ \\
\hline
\end{tabular}

Note: Italics indicate the correct answer.

Source: https://gflec.org/education/questions-that-indicate-financial-literacy

We assess personality traits using the short version of the "Big Five" personality traits questionnaire proposed by Gosling, Rentfrow, and Swann (2003) in what they call ten-item personality inventory (TIPI) ${ }^{21}$. We report the authors' description of TIPI in what follows (Gosling et al., 2003, p. 525):

\footnotetext{
${ }^{21}$ Pan and Statman (2013) instead measure extraversion on a scale ranging from -10 to +10 , where higher numbers indicate higher levels of extraversion. They measure openness, agreeableness, and conscientiousness similarly on scales ranging from $-20 \mathrm{a}+20$. All personality factors are then rescaled in a range of 0 to 1 .
} 


\section{Table 4. Questionnaire}

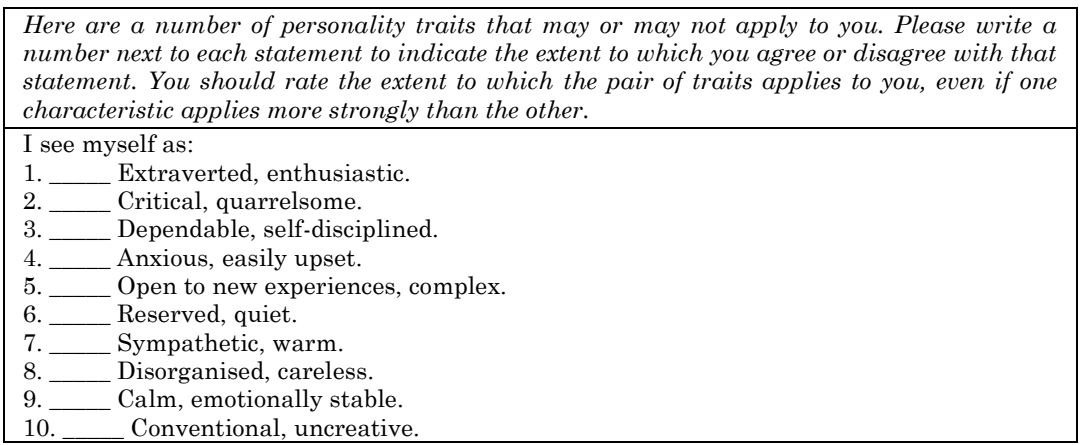

Notes: Respondents may choose on a range between 1 and 7 where: $1=$ disagree strongly, $2=$ disagree moderately, $3=$ neither agree nor disagree, $4=$ disagree a little, $5=$ agree a little, $6=$ agree moderately, $7=$ agree strongly .

TIPI scale scoring ("R" denotes reverse-scored items): extraversion: $1,6 \mathrm{R}$; agreeableness: $2 \mathrm{R}, 7$; conscientiousness: $3,8 \mathrm{R}$; emotional stability: 4R, 9; openness to experiences: 5, 10R.

We then use the five questions proposed by Pan and Statman (2013) to measure overconfidence, propensity to regret, propensity to trust, perception of luck vs. skill (that we rename as "luck"), and propensity to maximisation. All questions were based on a 10-point Likert scale, ranging from 1 to 10, as shown in Table 5 .

Table 5. Behavioural and individual propensities questions

\begin{tabular}{|l|l|c|}
\hline & \multicolumn{1}{|c|}{ Question } & Range \\
\hline Luck & $\begin{array}{l}\text { Some people believe that success in picking stocks that earn } \\
\text { higher-than-average returns is mostly due to skill. Other } \\
\text { people believe that success in picking stocks that earn higher- } \\
\text { than-average returns is mostly due to luck. }\end{array}$ & $1-10$ \\
\hline Regret & $\begin{array}{l}\text { Whenever I make a choice, I try to get information about how } \\
\text { the other alternatives turned out and feel bad if another } \\
\text { alternative has done better than the alternative I have chosen. }\end{array}$ & $1-10$ \\
\hline Trust & $\begin{array}{l}\text { Generally speaking, would you agree that most people can be } \\
\text { trusted, or that you always have to be careful in dealing with } \\
\text { people other than your family? }\end{array}$ & $1-10$ \\
\hline Overconfidence & $\begin{array}{l}\text { Some people believe that they can pick stocks that would earn } \\
\text { higher-than-average returns. Other people believe that they } \\
\text { are unable to do so. }\end{array}$ & $1-10$ \\
\hline $\begin{array}{l}\text { Propensity to } \\
\text { maximization }\end{array}$ & $\begin{array}{l}\text { I always want to have the best. The second best is not good } \\
\text { enough for me. }\end{array}$ & $1-10$ \\
\hline
\end{tabular}

Source: Pan and Statman (2013).

For the questions on regret, trust, and propensity to maximization, scores range from 1 "completely disagree" to 10 "completely agree". For the question on luck, scores range from 1 "I believe that success in picking stocks that earn higher-than-average returns is mostly due to skill" to 10 "I believe that success in picking stocks that earn 
higher-than-average returns is mostly due to luck". For the question on overconfidence scores range from 1 "I believe that I cannot pick stocks that would earn higher-than-average returns" to 10 "I believe that I can pick stocks that would earn higher-than-average returns".

To complete the information provided by respondents, we inserted in the questionnaire questions to collect demographic and socio-economic information on age, gender, education levels (measured in terms of school years), and income.

\subsection{Results}

In Table 6, we present the descriptive analysis ${ }^{22}$ of the main financial decision variables including demographics and socio-economic ones, financial literacy, behavioural aspects, and personality traits.

The sample age mean is $33.51(S D=14.46)$, but the distribution is skewed toward younger respondents (18-35) that constitute about $60 \%$ of the entire sample.

Respondents are almost equally distributed between females $(N=2,698 ; 51.1 \%$ of the sample $)$ and males $(N=2,580 ; 48.9 \%$ of the sample).

Table 6. Demographic and socioeconomic variables description

\begin{tabular}{|c|c|c|c|c|c|}
\hline & Coding & No. & Percentage $\%$ & Cumulative $\%$ & $\boldsymbol{p}$ \\
\hline Age & & & & & $* * *$ \\
\hline $18-25$ & 1 & 2,491 & 41.1 & 47.2 & \\
\hline $26-35$ & 2 & 1,132 & 18.7 & 68.6 & \\
\hline $36-45$ & 3 & 429 & 8.1 & 76.8 & \\
\hline $46-55$ & 4 & 606 & 11.5 & 88.3 & \\
\hline $56-65$ & 5 & 474 & 9.0 & 97.2 & \\
\hline $65-75$ & 6 & 105 & 2.0 & 99.2 & \\
\hline$>75$ & 7 & 41 & 0.8 & 100 & \\
\hline Gender & & & & & $* * *$ \\
\hline Female & 1 & 2,698 & 51.1 & 51.1 & \\
\hline Male & 2 & 2,580 & 48.9 & 100 & \\
\hline $\begin{array}{c}\text { Education } \\
\text { (school years) }\end{array}$ & & & & & $* * *$ \\
\hline$<9$ & 1 & 2,810 & 46.4 & 53.2 & \\
\hline $9-12$ & 2 & 1,368 & 22.6 & 79.2 & \\
\hline$>12$ & 3 & 1,047 & 17.3 & 99.0 & \\
\hline Prefer not to say & 99 & 53 & 0.9 & 100 & \\
\hline Income (in $\boldsymbol{\epsilon}$ ) & & & & & $* * *$ \\
\hline$<10,000$ & 1 & 615 & 11.7 & 11.7 & \\
\hline $10,000-20,000$ & 2 & 1,229 & 23.3 & 34.9 & \\
\hline $20,001-40,000$ & 3 & 1,505 & 28.5 & 63.5 & \\
\hline $40,001-80,000$ & 4 & 501 & 9.5 & 72.9 & \\
\hline$>80,000$ & 5 & 169 & 3.2 & 76.1 & \\
\hline Prefer not to say & 99 & 1,259 & 23.9 & 100 & \\
\hline
\end{tabular}

${ }^{22}$ Regarding the variables on education and income levels, options "other", "do not know" and "refuse to answer", coded respectively as 98 and 99, were omitted from the descriptive analysis to avoid abnormal fluctuations in the values of the average and, consequently, of the standard deviation. 
Almost half (46.4\%) of respondents have less than 9 school years, $22.6 \%$ of them between 9 and 12 years, and $17.3 \%$ more than 12 . In terms of income, $11.7 \%$ of respondents have less than 10,000 euros, $23.3 \%$ of them are between 10,000 and 20,000 euros, $23.3 \%$ between 20,001 and 40,000 euros, $9.5 \%$ between 40,001 and 80,000 euros, just $3.2 \%$ above 80,000 euros and $23.9 \%$ prefer not to disclose their income.

In Table 7 we present our regression models.

Table 7. Regressions models of personality traits and socioeconomic variables on financial literacy score, luck, regret, trust, overconfidence and propensity to maximization

\begin{tabular}{|c|c|c|c|c|c|c|}
\hline & Model 1 & Model 2 & Model 3 & Model 4 & Model 5 & Model 6 \\
\hline & $\begin{array}{c}\text { Financial } \\
\text { literacy } \\
\text { score }\end{array}$ & Luck & Regret & Trust & $\begin{array}{c}\text { Over- } \\
\text { confidence }\end{array}$ & $\begin{array}{c}\text { Propensity } \\
\text { to maximi- } \\
\text { zation }\end{array}$ \\
\hline Extraversion & $\begin{array}{c}-0.062^{* * * *} \\
(0.015)\end{array}$ & $\begin{array}{c}0.102^{* * *} \\
(0.021)\end{array}$ & & $\begin{array}{c}0.007 \\
(0.022)\end{array}$ & $\begin{array}{c}0.083^{* * *} \\
(0.021)\end{array}$ & $\begin{array}{c}0.126^{* * *} \\
(0.024)\end{array}$ \\
\hline Conscientiousness & $\begin{array}{c}0.031^{* *} \\
(0.012)\end{array}$ & $\begin{array}{c}-0.049^{* * *} \\
(0.018)\end{array}$ & $\begin{array}{l}0.089^{* *} \\
(0.024)\end{array}$ & $\begin{array}{c}0.067^{* * *} \\
(0.019)\end{array}$ & $\begin{array}{c}-0.016^{* * *} \\
(0.017)\end{array}$ & $\begin{array}{c}-0.004 \\
(0.020) \\
\end{array}$ \\
\hline $\begin{array}{l}\text { Openness to } \\
\text { experiences }\end{array}$ & $\begin{array}{c}-0.077^{* * *} \\
(0.016)\end{array}$ & $\begin{array}{c}0.020 \\
(0.023)\end{array}$ & $\begin{array}{c}0.070^{* * *} \\
(0.022)\end{array}$ & $\begin{array}{c}0.024 \\
(0.024)\end{array}$ & $\begin{array}{c}0.044^{* * *} \\
(0.023)\end{array}$ & $\begin{array}{c}0.074^{* * * *} \\
(0.026)\end{array}$ \\
\hline Agreeableness & $\begin{array}{c}-0.050^{* *} \\
(0.017)\end{array}$ & $\begin{array}{c}0.009 \\
(0.025)\end{array}$ & $\begin{array}{c}0.089^{* * *} \\
(0.024)\end{array}$ & $\begin{array}{c}0.115^{* * *} \\
(0.026)\end{array}$ & $\begin{array}{l}0.031^{* *} \\
(0.025)\end{array}$ & $\begin{array}{c}0.007 \\
(0.028)\end{array}$ \\
\hline $\begin{array}{l}\text { Emotional } \\
\text { stability }\end{array}$ & $\begin{array}{c}0.116^{* * *} \\
(0.017)\end{array}$ & $\begin{array}{c}0.082^{* * * *} \\
(0.018)\end{array}$ & $\begin{array}{c}-0.140^{* * * *} \\
(0.012)\end{array}$ & $\begin{array}{c}-0.122^{* * *} \\
(0.018)\end{array}$ & $\begin{array}{c}0.020 \\
(0.017)\end{array}$ & $\begin{array}{c}0.019 \\
(0.020)\end{array}$ \\
\hline Age & $\begin{array}{c}0.087^{* * *} \\
(0.002)\end{array}$ & $\begin{array}{c}0.093^{* * *} \\
(0.002)\end{array}$ & $\begin{array}{c}0.022 \\
(0.002)\end{array}$ & $\begin{array}{c}0.071^{* * *} \\
(0.002)\end{array}$ & $\begin{array}{c}-0.070^{* * * *} \\
(0.002)\end{array}$ & $\begin{array}{c}-0.167^{* * *} \\
(0.002)\end{array}$ \\
\hline Gender & $\begin{array}{c}-0.177 * * * \\
(0.043)\end{array}$ & $\begin{array}{c}0.016 \\
(0.061) \\
\end{array}$ & $\begin{array}{c}-0.034^{* * * *} \\
(0.058)\end{array}$ & $\begin{array}{c}-0.023^{*} \\
(0.063)\end{array}$ & $\begin{array}{c}-0.138^{* * * *} \\
(0.060)\end{array}$ & $\begin{array}{c}-0.196^{* * *} \\
(0.069)\end{array}$ \\
\hline Education & $\begin{array}{c}0.033^{* * *} \\
(0.001)\end{array}$ & $\begin{array}{l}-0.012 \\
(0.003)\end{array}$ & $\begin{array}{l}-0.023^{*} \\
(0.003)\end{array}$ & $\begin{array}{l}-0.003 \\
(0.003)\end{array}$ & $\begin{array}{l}-0.003 \\
(0.005)\end{array}$ & $\begin{array}{c}0.036^{* *} \\
(0.004)\end{array}$ \\
\hline Household income & $\begin{array}{c}0.140^{* * *} \\
(0.001)\end{array}$ & $\begin{array}{l}0.032^{* *} \\
(0.001)\end{array}$ & $\begin{array}{c}-0.014 \\
(0.001)\end{array}$ & $\begin{array}{l}-0.004 \\
(0.001)\end{array}$ & $\begin{array}{l}0.023^{*} \\
(0.001)\end{array}$ & $\begin{array}{c}0.006 \\
(0.001)\end{array}$ \\
\hline$\sigma$ & 1.499 & 2.14 & 2.00 & 2.23 & 2.11 & 2.44 \\
\hline Adjusted $\mathrm{R}^{2}$ & & & & 0.031 & 0.044 & 0.109 \\
\hline No. observations & 5.278 & 5.278 & 5.278 & 5.278 & 5.278 & 5.278 \\
\hline
\end{tabular}

Note: Standard errors in parentheses. Bold coefficients are statistically significant.

In Model 1, we present the results with respect to the financial literacy score. All the coefficients associated with the explanatory variables are statistically significant. All the coefficients associated with personality traits are statistically significant. Conscientiousness and emotional stability have a positive effect on financial literacy, instead, extraversion, openness to experiences, and agreeableness have a negative one. Previous studies in the literature (Duckworth \& Weir, 2011) showed that conscientiousness plays a major role in the economic and financial realms. Thus, a positive effect on the financial literacy score is in line with our expectations. It could be the case that more conscientious people devote more time to improve their financial literacy, acknowledging its importance in their life. A possible alternative 
explanation is that since higher conscientiousness is associated with lower risk tolerance (Pan \& Statman, 2013), more conscientious people, being less risk-tolerant, may appreciate the benefits of being financially literate to better manage their investments risk.

The positive effect of emotional stability (the opposite of "neuroticism") 23 may be explained by the fact that emotionally stable people are calmer, not easily disturbed, or annoyed, they worry less about things. Instead, for emotionally unstable (neurotic) people the opposite holds. In the same vein, emotionally stable people may be more patient and willing to take their time to improve their financial literacy.

The negative effect of extraversion may be explained considering previous evidence showing that extraverted people tend to choose fields of study more related to social sciences such as philosophy, psychology, sociology, etc., and less to technical ones such as economics, engineering, etc. Thus, they may have, on average, less numeracy and, thus, lower degrees of financial literacy, as measured by answers to the "Big Five" question reported above. In addition, extraversion is also typically associated with high levels of overconfidence that leads to overestimating people's perception of their knowledge and skills. As reported in Chapter 2, a study of CONSOB, the supervisory authority responsible for regulating the Italian financial markets, shows that more overconfident respondents are less likely both to enrol in financial education programmes, not recognising their limited financial knowledge and to seek professional support from financial advisors, while instead heavily relying on informal advice from colleagues, friend, relatives, etc. (Linciano et al., 2017).

The negative coefficients associated with openness and agreeableness may be explained by the evidence that people scoring high in these personality traits, usually score low on conscientiousness (Pan \& Statman, 2013). People with high openness are also prone to conservatism (Pompian, 2012), and thus they may be less prone to enrol in financial education programmes. More agreeable people may instead seek more informal financial advice.

Age, education, and household income are positively related to financial literacy, in line with previous studies in the literature. Vice versa, again in line with the literature, gender has a negative coefficient, since men tend on average to record higher financial literacy scores than women.

In Model 2, we use as a dependent variable the propensity to attribute success to luck instead of ability, which we rename "luck". Not all the coefficients associated with explanatory variables are statistically significant. In contrast with Pan and Statman (2013), that find extraversion to be negatively associated with the luck variable, we

\footnotetext{
${ }^{23}$ Pan and Statman (2013) do not analyse neuroticism, thus we cannot compare our results with theirs in this respect.
} 
find a positive relationship. In line with them, instead, we find that a negative coefficient for conscientiousness. Instead, in contrast with Pan and Statman (2013), we find agreeableness and openness to experiences not to be statistically significant.

We find a positive coefficient for emotional stability. A possible explanation is that attributing success to skill instead of luck may expose people to potential regret, but also to greater anxiety.

In contrast with Pan and Statman (2013), we find gender.

We find statistically significant positive coefficients for age and household income, while education and gender are not statistically significant. Pan and Statman (2013) find age not to be statistically significant in relation to luck and do not analyse the role of education and household income.

In Model 3, we use as a dependent variable the propensity to regret. All the coefficients associated with personality traits are statistically significant with the exception of extraversion. In line with Pan and Statman (2013), we find that conscientiousness is positively related to regret. They find openness to experiences and agreeableness not to be statistically significant; instead, we find them to be positively associated with the propensity to regret. In addition, we find that emotional stability impact negatively the propensity to regret, in line with our intuition that more anxious people are more prone to this propension. In contrast with Pan and Statman (2013) that find a negative relationship between age and regret, we find it not to be significant. In our sample, it seems that women are less propense to regret, in contrast to what Pan and Statman (2013) find. A possible explanation is that since women tend to attribute success more to luck than to skill, they may also be less exposed to feel regret in case of bad outcomes, compared to men. We finally find that income and education are negatively related to regret, suggesting that wealthier and more educated respondents are less inclined to it.

In Model 4, we use propensity to trust others ("trust" from now on) as a dependent variable. With respect to trust, Pan and Statman (2013) find positive coefficients for agreeableness, extraversion, and openness to experiences and negative ones for conscientiousness. We find the same signs only for agreeableness openness to experiences, while for conscientiousness we find a negative sign and extraversion appears not to be statistically significant in our regression. We also find emotional stability to be negatively related to trust. More anxious people thus seem to trust others less. In line with Pan and Statman (2013) we also find that, with respect to younger people, older ones tend to be more prone to trust others, while men seem to trust others more than women ${ }^{24}$. Finally, we find no statistically significant coefficients for both education and household income.

\footnotetext{
${ }^{24}$ As a matter of fact, Pan and Statman (2013) find a statistically significant effect for gender also for respondents scoring high in agreeableness.
} 
In Model 5, we use overconfidence as a dependent variable. Almost all the coefficients associated with the explanatory variables are statistically significant, with the exceptions of emotional stability and education. Among personality traits, we find positive coefficients for agreeableness, extraversion and openness to experiences, and, instead, a negative one for conscientiousness ${ }^{25}$. As previously found in several studies in the literature (Barber \& Odean, 2001), men tend to be more overconfident than women and overconfidence decreases with age. It also increases with household income.

In Model 6, we use as a dependent variable the propensity to maximization. Among personality traits, we find only extraversion, and openness to experiences to be statistically significant, with positive coefficients. While our evidence on extraversion is in line with the results of Pan and Statman (2013), they find a negative coefficient for openness to experiences. In addition, we find that the propensity to maximisation is positively related to education and negatively related to age and gender. These results suggest that more educated and younger respondents are more propense to maximisation than less educated and older ones, and that men are more inclined to maximisation with respect to women.

\section{References}

1. Barber, B. M., \& Odean, T. (2001). Boys will be boys: Gender, overconfidence, and common stock investment. The Quarterly Journal of Economics, 116(1), 261-292. https://doi.org/10.1162/003355301556400

2. Barberis, N., \& Thaler, R. (2003). A survey of behavioral finance. In G. M. Constantinides, M. Harris, \& R. M. Stulz (Eds.), Handbook of the economics of finance (Vol. 1, Part B, pp. 1053-1128). https://doi.org/10.1016/S1574-0102(03)01027-6

3. Bernheim, B. D., Garrett, D. M., \& Maki, D. M. (2001). Education and saving: The long-term effects of high school financial curriculum mandates. Journal of public Economics, 80(3), 435-465. https://doi.org/10.1016/S00472727(00)00120-1

4. Berti, A. E., Bombi, A. S., \& Duveen, G. T. (1988). The child's construction of economics. Cambridge, the UK: Cambridge University Press.

5. Borghans, L., Duckworth, A. L., Heckman, J. J., \& ter Weel, B. (2008). The economics and psychology of personality traits. The Journal of Human Resources, 43(4), 972-1059. https://doi.org/10.3368/jhr.43.4.972

6. Cesarini, D., Dawes, C. T., Johannesson, M., Lichtenstein, P., \& Wallace, B. (2009). Genetic variation in preferences for giving and risk taking. The Quarterly Journal of Economics, 124(2), 809-842. https://doi.org/10.1162/qjec.2009.124.2.809

\footnotetext{
${ }^{25}$ Pan and Statman (2013) find a statistically significant effect for extraversion (positive coefficient) and agreeableness (negative coefficient), while openness and conscientiousness are not statistically significant in their sample.
} 
7. Cronqvist, H., \& Siegel, S. (2014). The genetics of investment biases. Journal of Financial Economics, 113(2), 215-234. https://doi.org/10.1016/j.jfineco.2014.04.004

8. Disney, R., \& Gathergood, J. (2013). Financial literacy and consumer credit portfolios. Journal of Banking \& Finance, 37(7), 2246-2254. https://doi.org/10.1016/j.jbankfin.2013.01.013

9. Duckworth, A., \& Weir, D. (2011). Personality and response to the financial crisis (Michigan Retirement Research Center Research Paper No. WP 2011260). https://doi.org/10.2139/ssrn.2006595

10. Duflo, E., \& Saez, E. (2003). The role of information and social interactions in retirement plan decisions: Evidence from a randomized experiment. The Quarterly Journal of Economics, 118(3), 815-842. https://doi.org/10.1162/00335530360698432

11. Garcia, M. J. R. (2013). Financial education and behavioral finance: New insights into the role of information in financial decisions. Journal of Economic Surveys, 27(2), 297-315. https://doi.org/10.1111/j.14676419.2011.00705.x

12. Gosling, S. D., Rentfrow, P. J., \& Swann, W. B., Jr. (2003). A very brief measure of the Big-Five personality domains. Journal of Research in Personality, 37(6), 504-528. https://doi.org/10.1016/S0092-6566(03)00046-1

13. Hilgert, M. A., Hogarth, J. M., \& Beverly, S. G. (2003). Household financial management: The connection between knowledge and behaviour. Federal Reserve Bulletin, 89, 309-322. Retrieved from https://www.federalreserve.gov/pubs/bulletin/2003/0703lead.pdf

14. IOSCO, \& OECD. (2018). The application of behavioural insights to financial literacy and investor education programmes and initiatives. Retrieved from https://www.oecd.org/finance/The-Application-of-Behavioural-Insights-toFinancial-Literacy-and-Investor-Education-Programmes-and-Initiatives.pdf

15. Kuhnen, C. M., \& Chiao, J. Y. (2009). Genetic determinants of financial risk taking. PloS One, 4(2), e4362. https://doi.org/10.1371/journal.pone.0004362

16. Kuhnen, C. M., \& Knutson, B. (2011). The influence of affect on beliefs, preferences, and financial decisions. Journal of Financial and Quantitative Analysis, 46(3), 605-626. https://doi.org/10.1017/S0022109011000123

17. Linciano, N., Soccorso, P., Di Cagno, D., Panaccione, L., Nicolini, G., Ploner, M., ... Rigoni, U. (2017). Challenges in ensuring financial competencies: Essays on how to measure financial knowledge, target beneficiaries and deliver educational programmes (CONSOB Working Papers No. 84). https://doi.org/10.2139/ssrn.3067333

18. Lusardi, A. (2008). Financial literacy: An essential tool for informed consumer choice? (NBER Working Paper No. 14084). https://doi.org/10.3386/w14084

19. Lusardi, A., \& Mitchell, O. S. (2011). Financial literacy around the world: An overview (NBER Working Paper No. 17107). https://doi.org/10.3386/w17107

20. Lusardi, A., Schneider, D., \& Tufano, P. (2015). The economic crisis and medical care use: Comparative evidence from five high-income countries. Social Science Quarterly, 96(1), 202-213. https://doi.org/10.1111/ssqu.12076

21. Lyons, A. C., Chang, Y., \& Scherpf, E. M. (2006). Translating financial education into behavior change for low-income populations. Journal of Financial Counseling and Planning, 17(2), 27-45. Retrieved from https://eric.ed.gov/?id=EJ1104369

22. McCrae, R. R., \& Costa, P. T. (1987). Validation of the five-factor model of personality across instruments and observers. Journal of Personality and Social Psychology, 52(1), 81-90. https://doi.org/10.1037/0022-3514.52.1.81 
23. Pan, C. H., \& Statman, M. (2012). Questionnaires of risk tolerance, regret, overconfidence, and other investor propensities. SCU Leavey School of Business Research Paper No. 10-05. https://doi.org/10.2139/ssrn.1549912

24. Pan, C. H., \& Statman, M. (2013). Investor personality in investor questionnaires. Journal of Investment Consulting, 14(1), 48-56. https://doi.org/10.2139/ssrn.2022339

25. Pompian, M. M. (Ed.). (2012). Behavioral finance and investor types: Managing behavior to make better investment decisions. https://doi.org/10.1002/9781119202417

26. Shefrin, H. (2019). Broadening the scope of financial literacy to incorporate self-control, budgeting, and heuristics. https://doi.org/10.2139/ssrn.3438681

27. Stango, V., \& Zinman, J. (2009). What do consumers really pay on their checking and credit card accounts? Explicit, implicit, and avoidable costs. American Economic Review, 99(2), 424-429. https://doi.org/10.1257/aer.99.2.424

28. Statman, M., \& Wood, V. (2004). Investment temperament. Journal of Investment Consulting, 7(1), 55-66.

29. van Rooij, M., Lusardi, A., \& Alessie, R. (2011). Financial literacy and stock market participation. Journal of Financial Economics, 101(2), 449-472. https://doi.org/10.1016/j.jfineco.2011.03.006 


\section{FINANCIAL LITERACY AS AN INDICATOR OF ECONOMIC INEQUALITIES BETWEEN ITALIAN REGIONS}

\subsection{Introduction}

According to Levine (2005), economic inequality hampers development and negatively impacts the financial system.

The disparity in regional economic development has been a hallmark of the Italian economy (Ciocca, 2003; Dall'Aglio, 2003; Felice, 2015; Malanima \& Daniele, 2007; Padoa-Schioppa, 2006; Stiglitz, 2013).

Early in Italian history, the levels of education and industrialization were higher in northern regions than in southern ones (Vecchi, 2012).

Over decades, this disparity has increased resulting in high economic inequality (Felice, 2018). According to Myrdal (1957), significant wealth differences between regions caused, among other factors, the within-country dualism between North and South of Italy.

The OECD ranked Italy's level of income inequality as 12th among OECD countries (OECD, 2015), as displayed in Figure $1^{26}$.

Figure 1. Income distribution and inequality by OECD countries

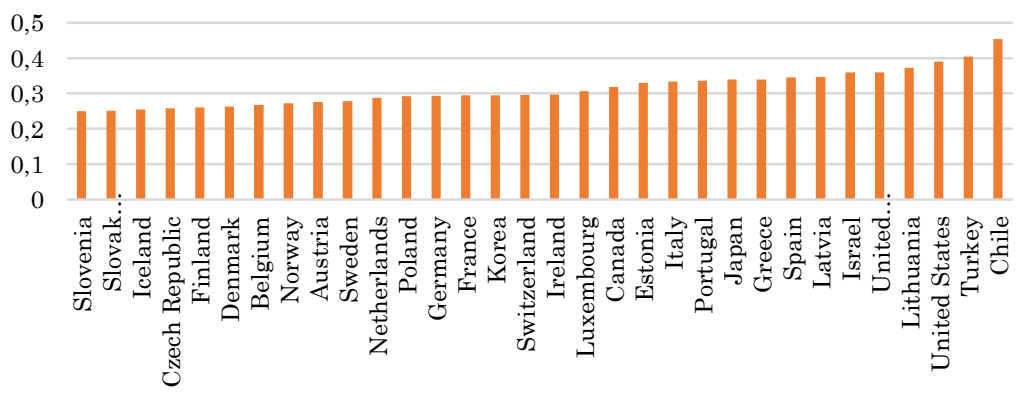

Following the Nomenclature of Territorial Units for Statistics 2 (hereinafter, NUTS) ${ }^{27}$, the Italian GDP at the end of 2016 confirms differences in wealth between regions.

\footnotetext{
${ }^{26}$ Australia, Hungary, Mexico and New Zealand are excluded because of lack of data.

${ }^{27}$ Classification based on NUTS 2 are: North East, North West, Centre, South, islands. We classify the twenty Italian regions accordingly: Emilia-Romagna, Friuli-Venezia Giulia, Trentino-Alto Adige and Veneto in the North East; Liguria, Lombardy, Piemonte e Valle d'Aosta in the North West; Lazio, Marche, Toscana and Umbria in the Centre; Abruzzo, Basilicata, Calabria, Campania, Molise and Puglia in the South; Sardinia and Sicily are the Islands.
} 
Northern regions record higher GDP compared to other regions and this difference is more significant between the North and the South. In Figure 2, regional GDP goes with colour intensity.

Figure 2. Italian regions by GDP (at current prices, by NUTS 2 regions)

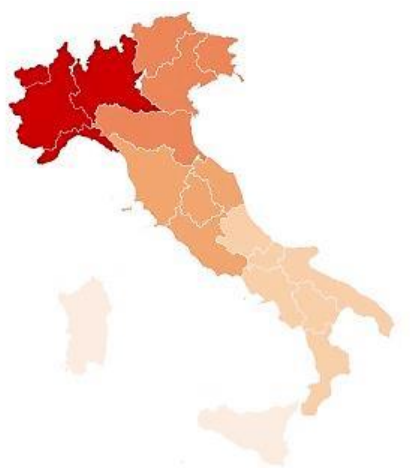

The existence of economic inequality inside a country is explained by the economic indicators as well as the social indicators ${ }^{28}$ (Felice, 2018).

Italian young adults in the southern and islands regions test lower in mathematics than the ones located in northern regions.

While northern Italian young people are similar to German ones in respect to math skills, young people in the South and the islands are like Turkish ones (OECD, 2014). These results show the presence of an intra-country dualism in financial literacy.

Literacy scores of the North and South show a significant difference in favour of the northern regions (Istat, 2017).

The consequences of these disparities in Italy prevent young people from having a homogeneous knowledge across the country, reducing their job opportunities later in life (Becker \& Chiswick, 1966) ${ }^{29}$.

The importance of having a good level of financial literacy is essential for proper decisions. OECD (2011) defines financial literacy as a "combination of awareness, knowledge, skills, attitude and behaviours necessary to make sound financial decisions and ultimately achieve individual's financial wellbeing".

\footnotetext{
${ }^{28}$ Social indicators can be defined as "statistic of direct normative interest which facilitates concise, comprehensive and balance judgments about the condition of major aspects of a society".

${ }_{29}$ The risk of poverty or social exclusion is higher in Italian southern regions compared to northern ones, highlighting both the strong relationship between education and economic development and the importance of investments in human capital which are fundamental to economic growth and mitigation of inequalities (Kucharčíková, 2014).
} 
Standard \& Poor's Global Finlit (Klapper, Lusardi, \& van Oudheusden, 2015) rated Italy as one of the lowest in Europe by financial literacy. To strengthen this evidence, the survey on Italians' savings behaviour and financial choices confirms that this problem is still persistent.

In what follows, we present our research design, starting from our hypotheses. The first one is the following:

H1: Financial literacy levels of Italian young adults are correlated with regional GDP.

Previous studies show that income is correlated with financial literacy (Bucher-Koenen, 2009; Lusardi \& Mitchell, 2014). Thus, regions with higher income would record higher levels of financial literacy ${ }^{30}$. Fornero and Monticone (2011) confirm that the Italian regions' GDP and financial literacy levels are indeed correlated. Furthermore, as also mentioned in Chapter 1, previous studies in the literature show that parents play a fundamental role in the financial literacy level of their children (Chiteji \& Stafford, 1999; Jorgensen, 2007; Jorgensen \& Savla, 2010; Pinto, Parente, \& Mansfield, 2005; Shim, Barber, Card, Xiao, \& Serido, 2010; Kim, LaTaillade, \& Kim, 2011). Young people learn financial concepts and behaviours, such as how to save, through the observation of parents' financial behaviour (Clarke, Heaton, Israelson, \& Eggert, 2005; Danes, 1994).

To find causal evidence to explain inequality in terms of financial literacy, in this chapter we analyse financial literacy at five Italian macro-regions following the indications provided by Eurostat with NUTS 2. To analyse the financial literacy rate, we use the questions proposed in Lusardi and Mitchell (2011). The results show that Italian young adults' financial literacy is a robust predictor of the related regional GDP.

The chapter is organised as follows: in subchapter 4.2, we describe the data and methodology; in subchapter 4.3, we illustrate the results; in subchapter 4.4 , we propose the chapter conclusions.

\subsection{Data and methodology}

Data used in this chapter were collected using a questionnaire. Respondents were Italian young adults including undergraduate students attending both economic and non-economic studies, and young adults not attending university. Overall, we collected 893 questionnaires, with respondents' ages ranging from 20 to 24 . The first section of the questionnaire collected socio-demographic information, while the focus of the second section was on financial literacy. To measure financial literacy, we used the "Big Three" questions. These questions have become a robust benchmark among scholars and authorities to

\footnotetext{
${ }^{30}$ Diacon and Maha (2015) show that in countries with higher GDP levels there is a positive association between income and GDP. This relevance is also verified for countries with lower GDP levels.
} 
assess people's financial literacy. As a matter of fact, the three fundamental questions of the HRS 2004 financial literacy model were developed to assess the three key financial concepts: compound interest rates, inflation, and risk diversification. The questions are as follows, and “*** indicates the right answer for each question:

1) Suppose you had $\$ 100$ in a savings account and the interest rate was $2 \%$ per year. After 5 years, how much do you think you would have in the account if you left the money to grow?

a) More than $\$ 102^{* *}$

b) Exactly $\$ 102$

c) Less than $\$ 102$

d) Do not know

e) Refuse to answer

2) Imagine that the interest rate on your savings account was $1 \%$ per year and inflation was $2 \%$ per year. After 1 year, how much would you be able to buy with the money in this account?

a) More than today

b) Exactly the same

c) Less than today**

d) Do not know

e) Refuse to answer

3)Please tell me whether this statement is true or false: "Buying a single company's stock usually provides a safer return than a stock mutual fund".

a) True

b) False **

c) Do not know

d) Refuse to answer

Following the methodology proposed by OECD, we consider the responses "do not know" and "refuse to answer" as wrong. Subsequently, the sample was divided by respondents' region of birth to investigate financial literacy levels by region.

\subsection{Results}

The demographic characteristics of the respondents show that $54 \%$ are male, that the average age is between 22 and 23 years old (Mean $=22.54$; $S D=1.52), 18.1 \%$ were attending an undergraduate economic course, $44.6 \%$ were enrolled in another (non-economic) undergraduate course and $37.3 \%$ were not attending any university course.

The respondents come from all the five Italian macro-regions: $16.2 \%$ of the sample from the North East, 19.6\% from North West, $24.6 \%$ from the Centre, $24.6 \%$ from the South and $15 \%$ from the islands. 


\subsubsection{Financial literacy results}

The first question measures the knowledge on "compounding". As we show in Table 8, young adults from northern regions obtain similar performances compared to the ones from central regions, while the percentage of correct answers is much lower in southern regions and in the islands.

Table 8. Compound interest rates knowledge

\begin{tabular}{|c|c|c|c|c|c|}
\hline \multirow{2}{*}{\multicolumn{3}{|c|}{ Numeracy crosstabulation }} & \multicolumn{2}{|c|}{ Numeracy } & \multirow{2}{*}{ Total } \\
\hline & & & Wrong & Correct & \\
\hline \multirow{10}{*}{ Regions } & \multirow{2}{*}{ North East } & Count & 57 & 75 & 132 \\
\hline & & $\%$ within regions & $43.2 \%$ & $56.8 \%$ & $100 \%$ \\
\hline & \multirow{2}{*}{ North West } & Count & 68 & 91 & 159 \\
\hline & & \% within regions & $42.8 \%$ & $57.2 \%$ & $100.0 \%$ \\
\hline & \multirow{2}{*}{ Centre } & Count & 91 & 109 & 200 \\
\hline & & $\%$ within regions & $45.5 \%$ & $54.5 \%$ & $100 \%$ \\
\hline & \multirow{2}{*}{ Islands } & Count & 66 & 56 & 122 \\
\hline & & \% within regions & $54.1 \%$ & $45.9 \%$ & $100.0 \%$ \\
\hline & \multirow{2}{*}{ South } & Count & 103 & 97 & 200 \\
\hline & & \% within regions & $51.5 \%$ & $48.5 \%$ & $100 \%$ \\
\hline \multirow{2}{*}{\multicolumn{2}{|c|}{ Total }} & Count & 385 & 428 & 813 \\
\hline & & $\%$ within regions & $47.4 \%$ & $52.6 \%$ & $100 \%$ \\
\hline
\end{tabular}

The second question measures the knowledge on "inflation". In Table 9, we show the results highlighting a higher degree of correct answers with respect to the previous question in the South and islands regions, even though the gap with the North and Centre is still present.

Table 9. Inflation knowledge

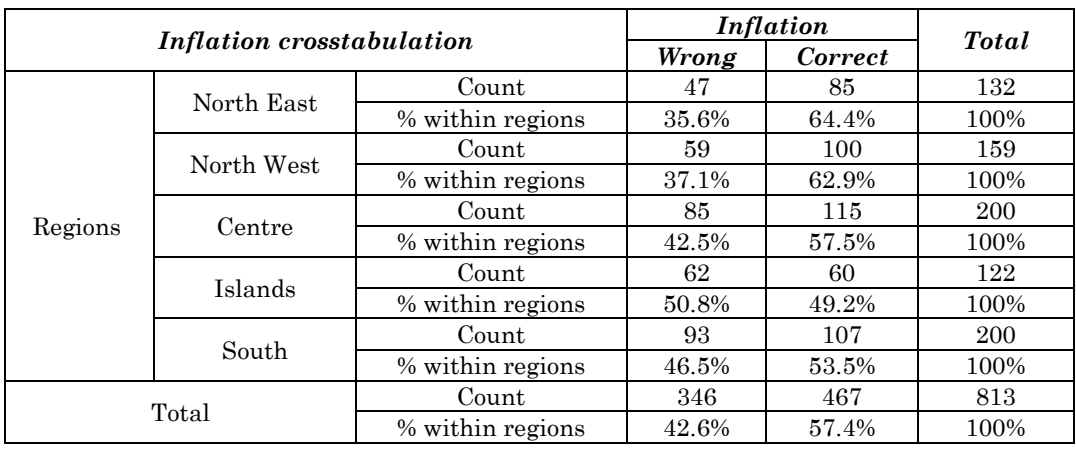

The third question measures the knowledge on risk "diversification". As shown in Table 10, the results are in line with the previous ones, i.e., young adults in the North and Centre regions answered more correctly compared to South and islands regions. 
Table 10. Diversification knowledge

\begin{tabular}{|c|c|c|c|c|c|}
\hline \multirow{2}{*}{\multicolumn{3}{|c|}{ Risk diversification crosstabulation }} & \multicolumn{2}{|c|}{$\begin{array}{c}\text { Risk } \\
\text { diversification }\end{array}$} & \multirow{3}{*}{$\begin{array}{c}\text { Total } \\
132 \\
\end{array}$} \\
\hline & & & Wrong & Correct & \\
\hline \multirow{10}{*}{ Regions } & \multirow{2}{*}{ North East } & Count & 48 & 84 & \\
\hline & & $\%$ within regions & $36.4 \%$ & $63.6 \%$ & $100.0 \%$ \\
\hline & \multirow{2}{*}{ North West } & Count & 59 & 100 & 159 \\
\hline & & $\%$ within regions & $37.1 \%$ & $62.9 \%$ & $100.0 \%$ \\
\hline & \multirow{2}{*}{ Centre } & Count & 84 & 116 & 200 \\
\hline & & $\%$ within regions & $42.0 \%$ & $58.0 \%$ & $100.0 \%$ \\
\hline & \multirow{2}{*}{ Islands } & Count & 66 & 56 & 122 \\
\hline & & $\%$ within regions & $54.1 \%$ & $45.9 \%$ & $100.0 \%$ \\
\hline & \multirow{2}{*}{ South } & Count & 108 & 92 & 200 \\
\hline & & $\%$ within regions & $54.0 \%$ & $46.0 \%$ & $100.0 \%$ \\
\hline \multirow{2}{*}{\multicolumn{2}{|c|}{ Total }} & Count & 365 & 448 & 813 \\
\hline & & $\%$ within regions & $44.9 \%$ & $55.1 \%$ & $100.0 \%$ \\
\hline
\end{tabular}

\subsubsection{Analysis of variance (ANOVA) results}

In Table 11, we present the results of the one-way analysis of variance (ANOVA) to verify our first assumption. The descriptive analysis of the results of the financial knowledge question shows that northern regions have different mean compared to regions in the Centre, South, and islands in Italy. In the northern regions, we can separately analyse the relative performance of the north-eastern (1.84) and north-western regions (1.83). Overall, it is evident that northern regions record better performances compared to the South (1.41) and the islands (1.41). Instead, Centre regions present better results (1.7) than southern ones (1.48), but lower than northern ones (respectively 1.84 for North West and 1.83 for North East) (see Table 11).

Table 11. Descriptive results

\begin{tabular}{|c|c|c|c|c|c|c|c|c|}
\hline & \multirow[t]{2}{*}{ No. } & \multirow[t]{2}{*}{ Mean } & \multirow{2}{*}{$\begin{array}{c}\text { Std. } \\
\text { deviation }\end{array}$} & \multirow{2}{*}{$\begin{array}{c}\text { Std. } \\
\text { error }\end{array}$} & \multicolumn{2}{|c|}{$\begin{array}{c}95 \% \text { confidence } \\
\text { interval for } \\
\text { mean }\end{array}$} & \multirow[t]{2}{*}{ Minimum } & \multirow[t]{2}{*}{ Maximum } \\
\hline & & & & & $\begin{array}{l}\text { Lower } \\
\text { bound }\end{array}$ & $\begin{array}{l}\text { Upper } \\
\text { bound }\end{array}$ & & \\
\hline $\begin{array}{l}\text { North } \\
\text { East }\end{array}$ & 132 & 1.8485 & 0.96887 & 0.08433 & 1.6817 & 2.0153 & 0.00 & 3.00 \\
\hline $\begin{array}{l}\text { North } \\
\text { West }\end{array}$ & 159 & 1.8302 & 0.98217 & 0.07789 & 1.6763 & 1.9840 & 0.00 & 3.00 \\
\hline Centre & 200 & 1.7000 & 0.95633 & 0.06762 & 1.5667 & 1.8333 & 0.00 & 3.00 \\
\hline Islands & 122 & 1.4098 & 0.95998 & 0.08691 & 1.2378 & 1.5819 & 0.00 & 3.00 \\
\hline South & 200 & 1.4800 & 1.07020 & 0.07567 & 1.3308 & 1.6292 & 0.00 & 3.00 \\
\hline Total & 813 & 1.6519 & 1.00521 & 0.03525 & 1.5827 & 1.7211 & 0.00 & 3.00 \\
\hline
\end{tabular}

In Figure 3, we illustrate the levels of financial literacy of young adults in our sample, following the NUTS 2 classification in the five macro-regions. 
Figure 3. Financial literacy regional inequalities

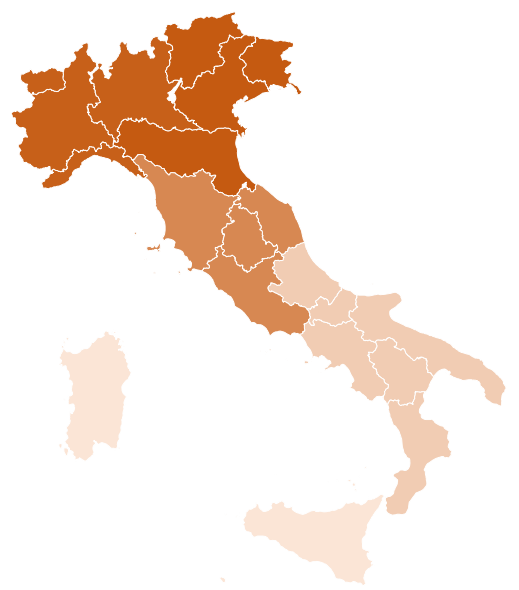

Young people located in the northern regions show higher financial knowledge than their peers living in Centre regions. This evidence is more pronounced when comparing North and South. Moreover, young Italian adults show similar levels of financial literacy to those provided by Fornero and Monticone (2011). The second ANOVA assumption is the homoscedasticity condition. In Table 12, we show that the results do not support this assumption $(p=0.032)$.

Table 12. Test of homogeneity of variances

\begin{tabular}{|l|c|c|c|c|}
\hline \multicolumn{1}{|c|}{ Financial literacy } & $\begin{array}{c}\text { Levene } \\
\text { statistic }\end{array}$ & $\boldsymbol{d f 1}$ & $\boldsymbol{d f 2}$ & $\boldsymbol{p}<\mathbf{0 . 0 5}$ \\
\hline based on mean & 2.647 & 4 & 808 & 0.032 \\
\hline based on median & 2.979 & 4 & 808 & 0.019 \\
\hline $\begin{array}{l}\text { based on median and with } \\
\text { adjusted df }\end{array}$ & 2.979 & 4 & 796.372 & 0.019 \\
\hline based on trimmed mean & 2.868 & 4 & 808 & 0.022 \\
\hline
\end{tabular}

Note: "df" stands for "degrees of freedom".

To check this issue, in Table 13 we present robust tests of equality of means. The results provided by Welch and Brown-Forsythe show that there are significant differences among means $(p=0.000)$.

Table 13. Robust tests of equality of means

\begin{tabular}{|l|c|c|c|c|}
\hline & Statistic $^{\boldsymbol{a}}$ & $\boldsymbol{d f 1}$ & $\boldsymbol{d f 2}$ & $\boldsymbol{p}<\mathbf{0 . 0 5}$ \\
\hline Welch & 5.984 & 4 & 380.189 & 0.000 \\
\hline Brown-Forsythe & 6.073 & 4 & 770.082 & 0.000 \\
\hline
\end{tabular}

Note: " $a$ " means asymptotically F distributed. 
To verify if the two means differ, in Table 14 we present a GamesHowell post hoc test analysis.

Table 14. Games-Howell post hoc tests analysis

\begin{tabular}{|c|c|c|c|c|c|c|}
\hline \multicolumn{2}{|c|}{ Games-Howell } & \multirow{2}{*}{$\begin{array}{c}\text { Mean } \\
\text { difference } \\
\quad(I-J)\end{array}$} & \multirow[b]{2}{*}{ Std. error } & \multirow[b]{2}{*}{$p<0.05$} & \multicolumn{2}{|c|}{$\begin{array}{c}95 \% \text { confidence } \\
\text { interval }\end{array}$} \\
\hline (I) regions & $\begin{array}{c}(J) \\
\text { regions }\end{array}$ & & & & $\begin{array}{l}\text { Lower } \\
\text { bound }\end{array}$ & $\begin{array}{l}\text { Upper } \\
\text { bound }\end{array}$ \\
\hline \multirow{4}{*}{ North East } & $\begin{array}{l}\text { North } \\
\text { West }\end{array}$ & 0.01830 & 0.11480 & 1.000 & -0.2969 & 0.3335 \\
\hline & Centre & 0.14848 & 0.10809 & 0.645 & -0.1483 & 0.4453 \\
\hline & Islands & $0.43865^{*}$ & 0.12110 & 0.003 & 0.1059 & 0.7714 \\
\hline & South & $0.36848^{*}$ & 0.11330 & 0.011 & 0.0575 & 0.6794 \\
\hline \multirow{4}{*}{ North West } & North East & -0.01830 & $\begin{array}{l}0.11480 \\
\end{array}$ & 1.000 & -0.3335 & 0.2969 \\
\hline & Centre & 0.13019 & 0.10315 & 0.715 & -0.1527 & 0.4131 \\
\hline & Islands & $0.42035^{*}$ & 0.11671 & 0.003 & 0.0998 & 0.7409 \\
\hline & South & $0.35019^{*}$ & 0.10860 & 0.012 & 0.0524 & 0.6480 \\
\hline \multirow{4}{*}{ Centre } & North East & -0.14848 & 0.10809 & 0.645 & -0.4453 & 0.1483 \\
\hline & $\begin{array}{l}\text { North } \\
\text { West }\end{array}$ & -0.13019 & 0.10315 & 0.715 & -0.4131 & 0.1527 \\
\hline & Islands & 0.29016 & 0.11012 & 0.067 & $\begin{array}{l}-0.0124 \\
\end{array}$ & 0.5927 \\
\hline & South & 0.22000 & 0.10149 & 0.194 & -0.0581 & 0.4981 \\
\hline \multirow{4}{*}{ Islands } & North East & $-0.43865^{*}$ & 0.12110 & 0.003 & -0.7714 & -0.1059 \\
\hline & $\begin{array}{l}\text { North } \\
\text { West }\end{array}$ & $-0.42035^{*}$ & 0.11671 & 0.003 & -0.7409 & -0.0998 \\
\hline & Centre & -0.29016 & 0.11012 & 0.067 & -0.5927 & 0.0124 \\
\hline & South & -0.07016 & 0.11524 & 0.974 & $\begin{array}{l}-0.3866 \\
\end{array}$ & 0.2463 \\
\hline \multirow{4}{*}{ South } & North East & $-0.36848^{*}$ & 0.11330 & 0.011 & -0.6794 & -0.0575 \\
\hline & $\begin{array}{l}\text { North } \\
\text { West }\end{array}$ & $-0.35019^{*}$ & 0.10860 & 0.012 & -0.6480 & -0.0524 \\
\hline & Centre & $\begin{array}{l}-0.22000 \\
\end{array}$ & $\begin{array}{l}0.10149 \\
\end{array}$ & 0.194 & -0.4981 & 0.0581 \\
\hline & Islands & 0.07016 & 0.11524 & 0.974 & -0.2463 & 0.3866 \\
\hline
\end{tabular}

Notes: * The mean difference is significant at the 0.05 level. Dependent variable: Financial literacy.

The results demonstrate that, in terms of financial literacy, the means of the North East and North West are significantly higher than the South and islands means $(p=0.011$ and $p=0.012 ; p=0.012$ and $\mathrm{p}=0.03)$.

The difference in mean could confirm that there is a presence of financial literacy inequality regarding young adults, among the Italian regions.

\subsubsection{Ordinary minimum squares (OLS) results}

To investigate the relationship between financial literacy and inequality, we first consider the Pearson correlations between the used variables. In Table 15, we show that financial literacy is positively and significantly correlated with GDP levels and negatively and significantly correlated with the Gini index ${ }^{31}$.

\footnotetext{
${ }^{31}$ The Gini index is a summary statistic that measures how equitably a resource is distributed in a population; income is a primary example. In addition to a self-contained presentation of the Gini index, we give two equivalent ways to interpret this summary statistic: first in terms of the percentile level of
} 
Table 15. Correlation matrix

\begin{tabular}{|c|c|c|c|c|c|c|c|c|}
\hline & & 1 & 2 & 3 & 4 & 5 & 6 & 7 \\
\hline \multirow{2}{*}{ 1. Age } & $\mathrm{PC}$ & 1 & $-0.072^{*}$ & $0.103^{* *}$ & -0.05 & $0.072^{*}$ & $-0.075^{*}$ & $0.150^{* * *}$ \\
\hline & $p<0.05$ & & 0.039 & 0.003 & 0.154 & 0.041 & 0.032 & 0 \\
\hline \multirow{2}{*}{ 2. Gender } & $\mathrm{PC}$ & & 1 & -0.035 & 0.056 & -0.051 & 0.008 & $-0.182^{* *}$ \\
\hline & $\mathrm{p}<0.05$ & & & 0.318 & 0.108 & 0.145 & 0.815 & 0 \\
\hline \multirow{2}{*}{ 3. Education } & $\mathrm{PC}$ & & & 1 & 0.034 & $-0.088^{*}$ & -0.046 & $0.087^{*}$ \\
\hline & $\mathrm{p}<0.05$ & & & & 0.332 & 0.012 & 0.186 & 0.013 \\
\hline \multirow{2}{*}{$\begin{array}{l}\text { 4. GDP (at current } \\
\text { prices) }\end{array}$} & $\mathrm{PC}$ & & & & 1 & $-0.664^{* *}$ & $0.201^{* *}$ & $0.145^{* *}$ \\
\hline & $p<0.05$ & & & & & 0 & 0 & 0 \\
\hline \multirow{2}{*}{ 5. Gini index } & $\mathrm{PC}$ & & & & & 1 & $-0.209^{* *}$ & $-0.136^{* *}$ \\
\hline & $\mathrm{p}<0.05$ & & & & & & 0 & \begin{tabular}{|l|}
0 \\
\end{tabular} \\
\hline \multirow{2}{*}{$\begin{array}{l}\text { 6. Financial } \\
\text { households situation }\end{array}$} & $\mathrm{PC}$ & & & & & & 1 & $0.084^{*}$ \\
\hline & $\mathrm{p}<0.05$ & & & & & & & 0.016 \\
\hline \multirow{2}{*}{ 7. Financial literacy } & $\mathrm{PC}$ & & & & & & & 1 \\
\hline & $\mathrm{p}<0.05$ & & & & & & & \\
\hline
\end{tabular}

The results presented in Tables 16 and 17 support the $H 1$ that financial literacy is a robust indicator of the economic inequalities presented in Figures 1 and 3.

Table 16. Regression Model 1 results

\begin{tabular}{|l|c|c|c|c|c|}
\hline & \multicolumn{2}{|c|}{ Unstandardized coefficients } & \multicolumn{3}{c|}{ Standardized coefficients } \\
\cline { 2 - 6 } & $\boldsymbol{B e t a}$ & $\boldsymbol{S E}$ & $\boldsymbol{B e t a}$ & $\boldsymbol{t}$ & $\boldsymbol{p}<\mathbf{0 . 0 5}$ \\
\hline Age & -4.947 & 3.03 & -0.057 & -1.633 & 0.103 \\
\hline Gender & 21.132 & 9.236 & 0.079 & 2.288 & $0.022^{*}$ \\
\hline Education & 3.156 & 2.826 & 0.038 & 1.117 & 0.264 \\
\hline $\begin{array}{l}\text { Financial } \\
\text { households } \\
\text { situation }\end{array}$ & 26.423 & 4.893 & 0.185 & 5.4 & $0.000^{* *}$ \\
\hline $\begin{array}{l}\text { Financial } \\
\text { literacy }\end{array}$ & 19.831 & 4.682 & 0.149 & 4235 & $0.000^{* *}$ \\
\hline $\mathrm{F}$ & 11667 & & & & \\
\hline $\mathrm{R}^{2}$ & 0.067 & & & & \\
\hline No. & 813 & & & & \\
\hline
\end{tabular}

Note: ${ }^{*} p<0.05 ; * * p<0.01$. Dependent variable: GDP current price.

Financial literacy is significant both to explain the GDP levels (regression Model 1) and inequalities (regression Model 2) between Italian regions. 
Table 17. Regression Model 2 results

\begin{tabular}{|l|c|c|c|c|c|}
\hline \multirow{2}{*}{} & \multicolumn{2}{|c|}{ Unstandardized coefficients } & \multicolumn{3}{c|}{ Standardized coefficients } \\
\cline { 2 - 6 } & $\boldsymbol{B e t a}$ & $\boldsymbol{S E}$ & Beta & $\boldsymbol{t}$ & $\boldsymbol{p}<\mathbf{0 . 0 5}$ \\
\hline Age & 0.001 & 0.000 & 0.082 & 2387 & $0.017^{*}$ \\
\hline Gender & -0.003 & 0.001 & -0.072 & -2.086 & $0.037^{*}$ \\
\hline Education & -0.001 & 0 & -0.096 & -2.807 & $0.005^{* *}$ \\
\hline $\begin{array}{l}\text { Financial } \\
\text { households } \\
\text { situation }\end{array}$ & -0.004 & 0.001 & -0.195 & -5.72 & $0.000^{* *}$ \\
\hline $\begin{array}{l}\text { Financial } \\
\text { literacy }\end{array}$ & -0.002 & 0.001 & -0.137 & -3.909 & $0.000^{* *}$ \\
\hline $\mathrm{F}$ & 13537 & & & & \\
\hline $\mathrm{R}^{2}$ & 0.077 & & & & \\
\hline No. & 813 & & & & \\
\hline
\end{tabular}

Note: ${ }^{*} p<0.05 ;{ }^{* *} p<0.01$. Dependent variable: Gini index.

\subsection{Concluding remarks and research perspectives}

The aim of this subchapter is to verify whether financial literacy is an indicator of economic inequality in Italy.

Italian young adults show different degrees of financial literacy from region to region. Young adults in regions with higher GDP values show better financial knowledge than those in regions with lower GDP levels.

This evidence is consistent with the literature proving the positive association between income and financial literacy (Hastings \& Mitchell, 2011; Johnson \& Sherraden, 2007; Klapper et al., 2015; Monticone, 2010).

Additionally, the results of this research are consistent with the evidence of the correlation between economic literacy and economic development (Jappelli, 2010).

The analysis presented in this chapter reinforces the results of Fornero and Monticone (2011) as the levels of financial literacy recorded by Italian households are reflected in the results obtained by young adults in this study.

This evidence suggests that studies on parents' influences on their children, especially in Italy, should be further investigated.

Economic development in Italy also depends on young adults' and households' capability to make effective financial decisions regardless of the region of provenience.

\section{References}

1. Alesina, A., \& Perotti, R. (1996). Income distribution, political instability, and investment. European Economic Review, 40(6), 1203-1228. https://doi.org/10.1016/0014-2921(95)00030-5 
2. Alesina, A., \& Rodrik, D. (1994). Distributive politics and economic growth. The Quarterly Journal of Economics, 109(2), 465-490. https://doi.org/10.2307/2118470

3. Becker, G. S., \& Chiswick, B. R. (1966). Education and the distribution of earnings. The American Economic Review, 56(1-2), 358-369. Retrieved from https://www.jstor.org/stable/1821299

4. Bucher-Koenen, T. (2009). Financial literacy and private old-age provision in Germany - Evidence from SAVE 2008 (MEA Discussion Paper No. 1922009). https://doi.org/10.2139/ssrn.1534664

5. Chen, H., \& Volpe, R. P. (1998). An analysis of personal financial literacy among college students. Financial Services Review, 7(2), 107-128. https://doi.org/10.1016/S1057-0810(99)80006-7

6. Chiteji, N. S., \& Stafford, F. P. (1999). Portfolio choices of parents and their children as young adults: Asset accumulation by African-American families. American Economic Review, 89(2), 377-380. https://doi.org/10.1257/aer.89.2.377

7. Ciocca, P. (2003, October 25). L'economia italiana: Un problema di crescita [The Italian economy: A problem of growth]. Paper presented at the 44th Riunione scientifica annuale della Società degli Economisti. Retrieved from https://www.bancaditalia.it/pubblicazioni/interventi-direttorio/int-dir2003/ciocca_25_10_03.pdf

8. Clarke, M. C., Heaton, M. B., Israelson, C. L., \& Eggert, D. L. (2005). The acquisition of family financial roles and responsibilities. Family and Consumer Sciences Research Journal, 33(4), 321-340. https://doi.org/10.1177/1077727X04274117

9. Dall'Aglio, V. (2003). La dinamica del reddito regionale italiano: Un'analisi non parametrica [The dynamic of Italian regional income: A non-parametric analysis]. Rivista Italiana degli Economisti, 8(3), 385-410. https://doi.org/10.1427/12527

10. Danes, S. M. (1994). Parental perceptions of children's financial socialization. Financial Counseling and Planning, 5(1), 127-149. Retrieved from https://www.semanticscholar.org/paper/Parental-perceptions-ofchildren\%27s-financial-Danes/f8220b671b17da6c5874c4b51c4659bdd3ebf2c8

11. Diacon, P.-E., \& Maha, L.-G. (2015). The relationship between income, consumption and GDP: A time series, cross-country analysis. Procedia Economics and Finance, 23, 1535-1543. https://doi.org/10.1016/S22125671(15)00374-3

12. Felice, E. (2015). Ascesa e declino: Storia economica d'Italia [Rise and fall: Economic history of Italy]. Bologna, Italy: Il Mulino.

13. Felice, E. (2018). The socio-institutional divide: Explaining Italy's long-term regional differences. The Journal of Interdisciplinary History, 49(1), 43-70. https://doi.org/10.1162/jinh_a_01231

14. Fornero, E., \& Monticone, C. (2011). Financial literacy and pension plan participation in Italy. Journal of Pension Economics \& Finance, 10(4), 547-564. https://doi.org/10.1017/S1474747211000473

15. Hastings, J. S., \& Mitchell, O. S. (2011). How financial literacy and impatience shape retirement wealth and investment behaviours (NBER Working Paper No. 16740). https://doi.org/10.3386/w16740

16. Hastings, J. S., Madrian, B. C., \& Skimmyhorn, W. L. (2012). Financial literacy, financial education, and economic outcomes (NBER Working Paper No. 18412). https://doi.org/10.3386/w18412 
17. Hilgert, M. A., Hogarth, J. M., \& Beverly, S. G. (2003). Household financial management: The connection between knowledge and behaviour. Federal Reserve Bulletin, 89, 309-322. Retrieved from https://www.federalreserve.gov/ pubs/bulletin/2003/0703lead.pdf

18. Istat. (2017). Il benessere equo e sostenibile in Italia [Fair and sustainable wellness in Italy] (BES 2017 Report). Retrieved from https://www.istat.it/ it/archivio/207259

19. Jappelli, T. (2010). Economic literacy: An international comparison. The Economic Journal, 120(548), F429-F451. https://doi.org/10.1111/j.14680297.2010.02397.x

20. Johnson, E., \& Sherraden, M. S. (2007). From financial literacy to financial capability among youth. Journal of Sociology \& Social Welfare, 34(3), 119-145. Retrieved from https://scholarworks.wmich.edu/jssw/vol34/iss3/7/

21. Jorgensen, B. L. (2007). Financial literacy of college students: Parental and peer influences (Doctoral dissertation, Virginia Tech). Retrieved from https://vtechworks.lib.vt.edu/handle/10919/35407

22. Jorgensen, B. L., \& Savla, J. (2010). Financial literacy of young adults: The importance of parental socialization. Family Relations, 59(4), 465-478. https://doi.org/10.1111/j.1741-3729.2010.00616.x

23. Kim, J., LaTaillade, J., \& Kim, H. (2011). Family processes and adolescents' financial behaviors. Journal of Family and Economic Issues, 32(4), 668-679. https://doi.org/10.1007/s10834-011-9270-3

24. Klapper, L., Lusardi, A., \& van Oudheusden, P. (2015). Financial literacy around the world: Insights from the Standard \& Poor's ratings services global financial literacy survey (World Bank Report). Retrieved from http://nzz-filesprod.s3-website-eu-west-1.amazonaws.com/files/1/8/1/2015-

Finlit_paper_17_F3_SINGLES_1.18658181.pdf

25. Kucharčíková, A. (2014). Investment in the human capital as the source of economic growth. Periodica Polytechnica Social and Management Sciences, 22(1), 29-35. https://doi.org/10.3311/PPso.7426

26. Levine, R. (2005). Finance and growth: Theory and evidence. In P. Aghion, \& S. N. Durlauf (Eds.), Handbook of economic growth (Vol. 1, Part A, pp. 865-934). https://doi.org/10.1016/S1574-0684(05)01012-9

27. Lusardi, A., \& Mitchell, O. S. (2011c). Financial literacy and planning: Implications for retirement wellbeing (NBER Working Paper No. 17078). https://doi.org/10.3386/w17078

28. Lusardi, A., \& Mitchell, O. S. (2014). The economic importance of financial literacy: Theory and evidence. Journal of Economic Literature, 52(1), 5-44. https://doi.org/10.1257/jel.52.1.5

29. Lusardi, A., Mitchell, O. S., \& Curto, V. (2010) Financial literacy among the young. The Journal of Consumer Affairs, 44(2), 358-380. https://doi.org/10.1111/j.1745-6606.2010.01173.x

30. Malanima, P., \& Daniele, V. (2007). Il prodotto delle regioni e il divario NordSud in Italia (1861-2004) [The product of regions and the North-South gap in Italy]. Rivista di Politica Economica, 97(3-4), 267-315. Retrieved from http://www.biblio.liuc.it/scripts/essper/schedaArticolo.asp?codice=2159758

31. Monticone, C. (2010). How much does wealth matter in the acquisition of financial literacy? The Journal of Consumer Affairs, 44(2), 403-422. https://doi.org/10.1111/j.1745-6606.2010.01175.x

32. Myrdal, G. (1957). Economic theory and under-developed regions (1st ed.). London, the UK: Gerald Duckworth \& Co. 
33. OECD INFE. (2011). Measuring financial literacy: Core questionnaire in measuring financial literacy: Questionnaire and guidance notes for conducting an internationally comparable survey of financial literacy. Retrieved from https://www.oecd.org/finance/financial-education/49319977.pdf

34. OECD. (2011). Divided we stand: Why inequality keeps rising. Retrieved from https://www.oecd.org/els/soc/dividedwestandwhyinequalitykeepsrising.htm

35. OECD. (2014). PISA 2012 results: What students know and can do (Rev. ed., Vol. 1). https://doi.org/10.1787/9789264208780-en

36. OECD. (2015). In it together: Why less inequality benefits all. Retrieved from https://www.oecd.org/social/in-it-together-why-less-inequality-benefits-all9789264235120-en.htm

37. Padoa-Schioppa, T. (2006). Mezzogiorno e crescita economica. L’industria, 27(1), 41-44. https://doi.org/10.1430/21807

38. Persson, T., \& Tabellini, G. (1994). Is inequality harmful for growth? The American Economic Review, 84(3), 600-621. Retrieved from https://www.jstor.org/stable/2118070

39. Pinto, M. B., Parente, D. H., \& Mansfield, P. M. (2005). Information learned from socialization agents: Its relationship to credit card use. Family and Consumer Sciences Research Journal, 33(4), 357-367. https://doi.org/10.1177/1077727X04274113

40. Shim, S., Barber, B. L., Card, N. A., Xiao, J. J., \& Serido, J. (2010). Financial socialization of first-year college students: The roles of parents, work, and education. Journal of Youth and Adolescence, 39(12), 1457-1470. https://doi.org/10.1007/s10964-009-9432-x

41. Skagerlund, K., Lind, T., Strömbäck, C., Tinghög, G., \& Västfjäll, D. (2018). Financial literacy and the role of numeracy - How individuals' attitude and affinity with numbers influence financial literacy. Journal of Behavioural and Experimental Economics, 74, 18-25. https://doi.org/10.1016/ j.socec.2018.03.004

42. Smeeding, T. M., \& Phillips, K. R. (2002). Cross-national differences in employment and economic sufficiency. The ANNALS of the American Academy of Political and Social Science, 580(1), 103-133. https://doi.org/10.1177/000271620258000105

43. Stiglitz, J. E. (2013). Il prezzo della disuguaglianza [The price of inequality]. Turin, Italy: Einaudi.

44. Vecchi, G. (2012). Sviluppo economico, benessere e disuguaglianza: Italia, 1861-2011 [Economic development, wellness and inequality: Italy 1861-2011]. Rivista di Storia Economica, 28(1), 177-196. https://doi.org/10.1410/36641

45. Xiao, J. J., Ahn, S. Y., Serido, J., \& Shim, S. (2014). Earlier financial literacy and later financial behaviour of college students. International Journal of Consumer Studies, 38(6), 593-601. https://doi.org/10.1111/ijcs.12122

46. Xu, L., \& Zia, B. (2012). Financial literacy around the world: An overview of the evidence with practical suggestions for the way forward (World Bank Policy Research Working Paper). https://doi.org/10.1596/1813-9450-6107 
Virtus Interpress

Gagarina Str. 9, 311

Sumy, 40000

Ukraine

www.virtusinterpress.org

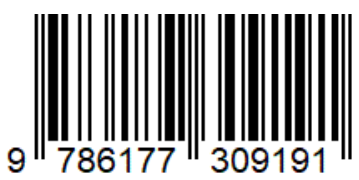




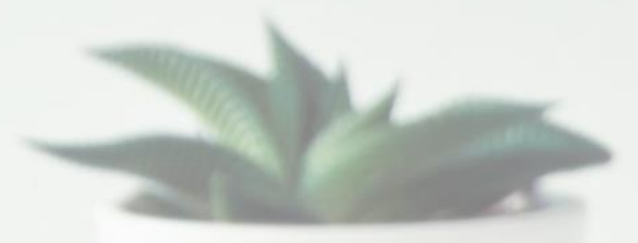

ISBN 978-617-7309-19-1

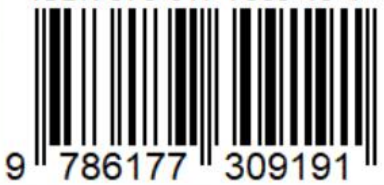

